
\title{
reprogramming in DIDO3 mutants with altered RNA processing and increased R-loop levels
}

\author{
Agnes Fütterer (DD ${ }^{1,3}$, Amaia Talavera-Gutiérrez ${ }^{1,3}$, Tirso Pons ${ }^{1}{ }^{1}$, Jesús de Celis ${ }^{1}$, Julio Gutiérrez ${ }^{1}$, Verónica Domínguez Plaza ${ }^{2}$ and \\ Carlos Martínez-A (iD ${ }^{1 凶}$
}

(C) The Author(s) 2021

\begin{abstract}
Embryonic stem cell (ESC) differentiation and somatic cell reprogramming are biological processes governed by antagonistic expression or repression of a largely common set of genes. Accurate regulation of gene expression is thus essential for both processes, and alterations in RNA processing are predicted to negatively affect both. We show that truncation of the DIDO gene alters RNA splicing and transcription termination in ESC and mouse embryo fibroblasts (MEF), which affects genes involved in both differentiation and reprogramming. We combined transcriptomic, protein interaction, and cellular studies to identify the underlying molecular mechanism. We found that DIDO3 interacts with the helicase DHX9, which is involved in R-loop processing and transcription termination, and that DIDO3-exon16 deletion increases nuclear R-loop content and causes DNA replication stress. Overall, these defects result in failure of ESC to differentiate and of MEF to be reprogrammed. MEF immortalization restored impaired reprogramming capacity. We conclude that DIDO3 has essential functions in ESC differentiation and somatic cell reprogramming by supporting accurate RNA metabolism, with its exon16-encoded domain playing the main role.
\end{abstract}

Cell Death and Disease (2021)12:637; https://doi.org/10.1038/s41419-021-03906-2

\section{INTRODUCTION}

Developmental differentiation and cell reprogramming are related biological processes that share certain common players and mechanisms [1]. Transcription networks are a hallmark, and include the pluripotency-related transcription factors OCT4, KLF4, and SOX2, all involved in self-renewal in pluripotent embryonic stem cells (ESC), as well as c-MYC (OKSM). These factors must be downregulated to permit ESC differentiation, and reexpressed for somatic cell reprogramming [2-4]. These transitions imply modifications in cell structures, cytoskeleton organization, cell polarity, and cell-cell contacts [5], all of which require changes in gene expression profiles.

Coordinated RNA processing and metabolism is a prerequisite for differentiation and reprogramming. Complex mechanisms such as RNA splicing [6,7], alternative termination [8], stability and transport [9], and expression regulation by miRNAs [10] are necessary. Growing evidence also links R-loop formation and dynamics to the physiological processing of gene regulation $[11,12]$. R-loops consist of a DNA/RNA hybrid that leaves the nontemplate DNA as single strand, a possible source of DNA breaks. Although initially described as transcription byproducts that threaten genome integrity, R-loops are important transcription regulators [11, 13-15] that participate in cell fate determination $[16,17]$ and somatic cell reprogramming [18]. Deregulation of Rloops leads to cell stress, especially when transcription meets replication [19-21]. RNA-binding proteins and splicing factors prevent R-loop formation, and processing factors such as $\mathrm{RNaseH}$ and helicases can dissolve them [22].

The DIDO gene participates in several of these processes. It is connected to chromatin remodeling processes and is stemnessrelated [23]. Its N-terminal truncation (DIDO $\Delta \mathrm{NT}$ ) leads to genomic instability [24, 25] and yields live mice, although they develop myeloid neoplasms [26]. In contrast, DIDO3 isoform-specific Cterminal deletion (DIDO3 $\triangle C T$ ) is embryonic lethal in mice; ESC derived from such mutants do not differentiate in vitro, but maintain self-renewal capacity [27]. DIDO3 is implicated in correct isoform splicing. DIDO3 $\triangle C T$ mutants do not express DIDO1, its smallest isoform [28], which must be upregulated during differentiation [23] and is involved in downregulation of stemness genes [28]. The DIDO3 and splicing factor SFPQ interaction was recently described, and DIDO3 was linked to correct, efficient RNA splicing [29].

Here we describe embryonic lethality of the conditional DIDO3 $\triangle E 16$ mutant. Its ESC failed to differentiate in vitro, and RNA-seq analysis showed isoform differences and aberrations in RNA termination. Among the genes affected we found POU5f1/ OCT4, and identified DIDO3 DNA binding at the POU5f1 3'UTR region. ChIP-seq analysis indicates a relationship between DIDO3 and RNA pol II binding and R-loops at the $3^{\prime}$ gene ends. This link is strengthened by DIDO3 $\mathrm{C}$ terminus interaction with the DHX9

\footnotetext{
${ }^{1}$ Department of Immunology and Oncology, Centro Nacional de Biotecnología (CNB-CSIC), 28049 Madrid, Spain. ${ }^{2}$ Transgenesis Unit, CNB \& Centro de Biología Molecular Severo Ochoa, CSIC-Universidad Autónoma de Madrid, 28049 Madrid, Spain. ${ }^{3}$ These authors contributed equally: Agnes Fütterer, Amaia Talavera-Gutiérrez. ${ }^{\circledR}$ email: cmartineza@cnb.csic.es. Edited by M. Agostini.
} 


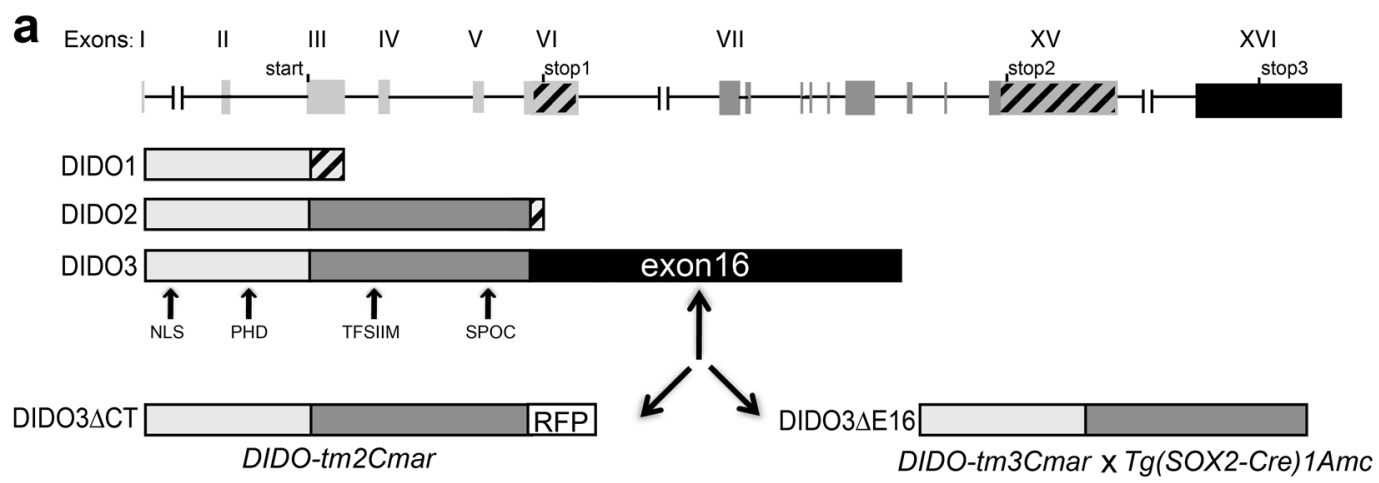

b

\begin{tabular}{|l|r|r|r|r|}
\hline day p.c. & total & wt & het & homo \\
\hline & & & & \\
\hline E7.5 & 25 & 5 & 8 & $12^{*}$ \\
\hline & & & & \\
\hline E8.5 & 24 & 6 & 15 & $3 \#$ \\
\hline
\end{tabular}

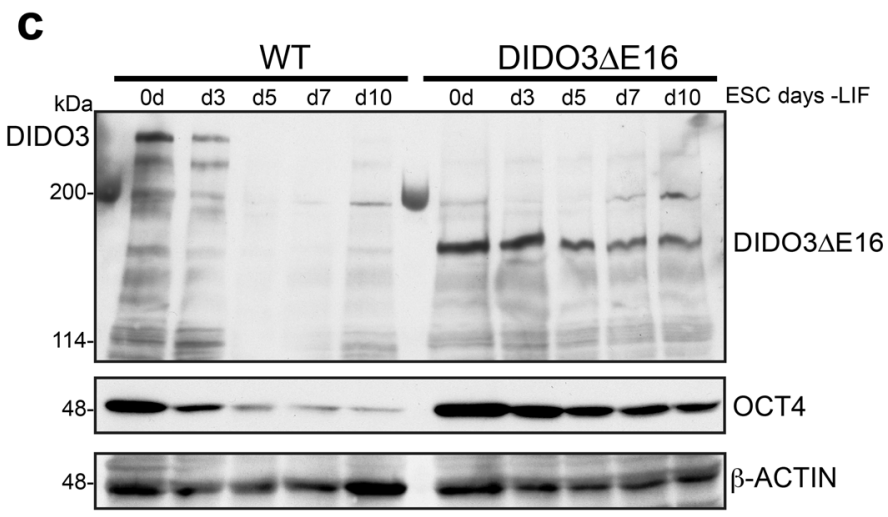

Fig. 1 DIDO3 $\triangle E 16$ mutant and its phenotype in vivo and in vitro. a DIDO gene structure and DIDO protein isoforms and their domains in WT, constitutive DIDO $3 \Delta C T$, and conditional DIDO3 $\Delta$ E16 mutants; NLS nuclear location signal, PHD plant homeodomain, TFSIIM transcription elongation factor S-II subunitM, SPOC Spen paralog and ortholog module, RFP red fluorescent protein. b Embryonic lethality at E7.5 and E8.5 post-coitum of DIDO3 $\Delta \mathrm{E} 16$ homozygous (homo) embryos compared to wild type (WT) and heterozygous (het) embryos. The asterisk $(*)$ indicates morphological anomalies and the octothorpe (\#), signs of resorption. c Western blot analysis of cell lysates from embryonic stem cells (ESC) and embryonic bodies at different times (d3, d5, d7, d10) after leukemia inhibitory factor (LIF) withdrawal from WT and DIDO3 $\Delta$ E16, tested by monitoring DIDO3 or DIDO3 $\triangle \mathrm{E} 16$ and OCT4 protein levels, using $\beta$-ACTIN as loading control.

helicase, by co-immunoprecipitation of both proteins with $\mathrm{R}$ loops, and by results from DHX9 knockdown experiments. We found higher R-loop levels in ESC and primary mouse embryonic fibroblasts (MEF) from DIDO3 $\triangle \mathrm{E} 16$ mutants, which result in DNA damage and lead to replication stress; primary MEF thus fails to undergo somatic cell reprogramming.

Based on these data, we propose a model that links ESC differentiation and somatic cell reprogramming with cell stress caused by impaired R-loop regulation, RNA splicing, and termination.

\section{RESULTS}

Embryonic lethality and ESC differentiation defects following conditional deletion of DIDO exon 16

We crossed DIDO-tm3Cmar mice bearing the floxed DIDO3specific exon16 with $\mathrm{Tg}(\mathrm{SOX} 2-\mathrm{Cre}) 1 \mathrm{Amc}$ mice [30] for Cremediated deletion (Fig. 1a). After intercrossing heterozygous $\mathrm{DIDO} 3 \Delta \mathrm{E} 16$ mice, we examined $\mathrm{F} 2$ embryos; there were no live embryos with homozygous deletion beyond d7.5 (Fig. 1b). Established homozygous ESC showed impaired differentiation in vitro, seen as persistence of OCT4 and DIDO3 $\triangle$ E16 after LIF (leukemia inhibitory factor) withdrawal (Fig. 1c), as described for constitutive deletion $[27,28]$. Here we refer to deletion of the floxed mutant as DIDO3 $\triangle \mathrm{E} 16$ and to the previous C-terminal deletion mutant as DIDO3 $\Delta \mathrm{CT}$; both affect the same exon 16 .

DIDO3 is implicated in alternative isoform splicing and RNA transcription termination

We isolated RNA from WT, DIDO3 $\triangle E 16$, and from DIDO $3 \triangle C T$ ESC reconstituted with HADIDO3, and performed stranded RNAsequencing (RNA-seq). We aligned sequences to the mouse reference genome (GRCm38/mm10 assembly) and analyzed data with the DEXSeq [31] program, which evaluates differential usage of exonic regions as a proxy for alternative isoform regulation. We found 290 exons with significant differences in WT compared to DIDO $3 \triangle \mathrm{E} 16 \mathrm{ESC}$, and almost all exons recovered normal expression in DIDO3 $\triangle \mathrm{CT}$ ESC after HADIDO3 reconstitution 
a

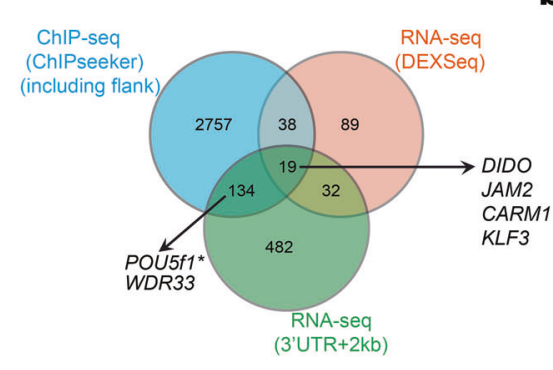

b

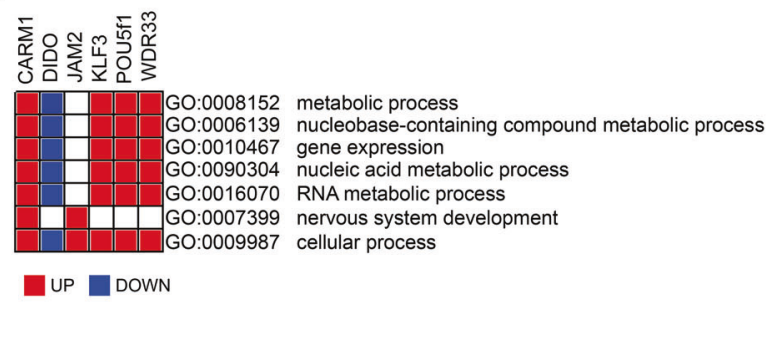

C

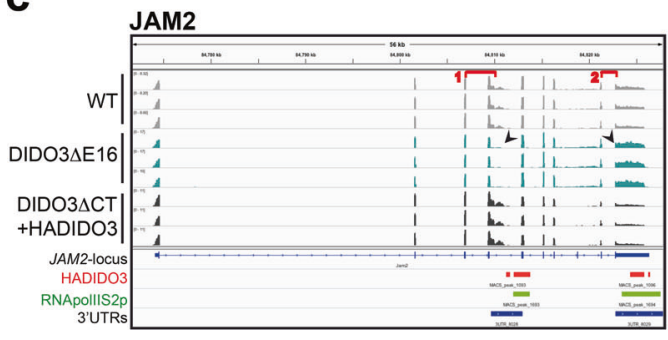

d

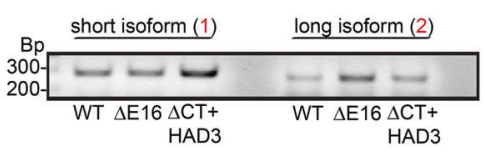

e

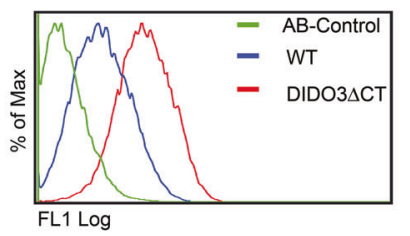

g

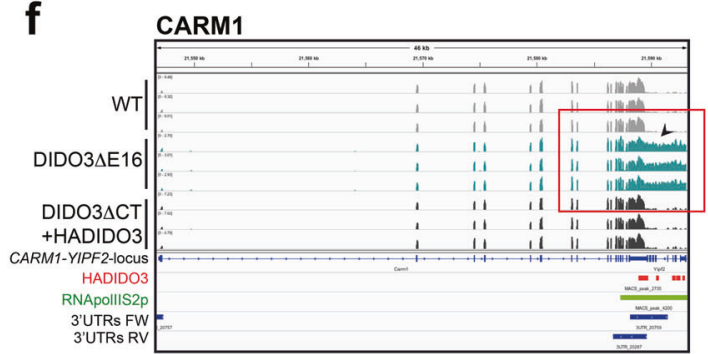

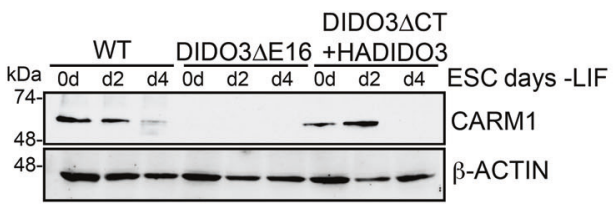

Fig. 2 DID03 $\triangle E 16$ ESC expression alterations detected by RNA-seq, with effects on protein expression. a The Venn diagram depicts the relationship of genes identified for altered expression in DIDO3 $\triangle E 16$ ESC compared to WT, and restored in DIDO3 $\triangle C T+H A D I D O 3$ in RNA-seq (DEXSeq, Supplementary Table 1; 3'UTR +2 kb, Supplementary Table 2), and a DIDO3 DNA-binding site determined by ChIPseeker of previous ChIP-seq data (Supplementary Table 3); some relevant examples are highlighted. Note: $\left(^{*}\right)$ Significant alteration $(1.5$-fold difference; FDR $<0.05)$ was not detected by RNA-seq data analysis, but RT-PCR confirmed a prolonged 3'UTR of the transcript only in the DIDO3 $\triangle E 16$ mutant ESC. For details, see Results. $\mathbf{b}$ GO term enrichment analysis and heatmap of the selected genes. UP- and DOWN regulated genes in DIDO3 $3 \mathrm{E} 16$ versus WT are shown in red and blue, respectively. Significantly enriched GO terms (biological processes) were identified using DAVID (https://david. ncifcrf.gov/), g: Profiler (https://biit.cs.ut.ee/gprofiler/gost), and GSEA (https://www.gsea-msigdb.org/). For additional details of the enrichment analysis, see Supplementary Fig. 1d. c JAM2 example gene; IGV image shows the JAM2 locus, aligned and normalized RNA-seq reads of triplicates of WT, DIDO3 $\Delta \mathrm{E} 16$, and DIDO3 $\Delta \mathrm{CT}+\mathrm{HADIDO} 3 \mathrm{ESC}$ as well as DIDO3 ChIP-seq peaks (red) with overlapping RNA pol II S2p peaks (green) and defined 3'UTR regions (blue). d Different abundance of JAM2 short isoform1 and long isoform2 (indicated in c), confirmed in WT, DIDO3 $\Delta \mathrm{E} 16$, and DIDO3 $\Delta+\mathrm{HADIDO} 3 \mathrm{RNA}$ as tested by RT-PCR. e The histogram shows abundance of the JAM2 protein in WT and DIDO3 $\Delta C T$ ESC as measured by flow cytometry analysis after anti-JAM2 antibody staining. $\mathbf{f}$ CARM1 example gene; parameters as in (b) for the CARM1 locus, focusing on $3^{\prime} U T R$ read-throughs in the DIDO3 $\triangle E 16$ mutant (red box). $\mathbf{g}$ Western blot analysis of lysates of ESC and embryonic bodies without LIF at d2 and d4, comparing CARM1 protein levels in WT, DIDO3 $\Delta$ E16, and DIDO3 $\triangle C T+H A D I D O 3$ cells; $\beta$-ACTIN used as loading control.

(Supplementary Table 1; Supplementary Fig. 1a). As predicted, DIDO was among the genes found and RNA-seq data confirmed the reported lack of splicing to the DIDO1 isoform [23, 28]; HADIDO3 reconstitution restored DIDO1 expression (Supplementary Fig. 1b).

For observed $3^{\prime} U T R$ read-throughs of transcripts, we reanalyzed the RNA-seq data and calculated expression differences with $2 \mathrm{~kb}$ added downstream of the defined 3'UTRs. Genes whose expression of prolonged $3^{\prime} \mathrm{UTR}$ in DIDO3 $\triangle \mathrm{E} 16$ recovered normal levels after reconstitution with HADIDO3 are shown (Supplementary Table 2).

As DIDO3 binds to chromatin [28], we tested whether expression alterations are linked to DIDO3-DNA binding, using data from ChIP-seq experiments ([28] GEO: GSE85029). HADIDO3 peaks were found preferentially in genome regions with a high density of gene coding sequences (Supplementary Fig. 1c). We associated HADIDO3 binding sites to the gene with the nearest transcription start site (TSS) and to flanking genes (up to $5 \mathrm{~kb}$ ) and reanalyzed the ChIP-seq peaks with the ChIPseeker program [32], which identified peak location (Supplementary Table 3). Combined analysis of ChIP- and RNA-seq data showed candidate genes with expression alterations in DIDO3 $\triangle \mathrm{E} 16 \mathrm{ESC}$ when recovered by HADIDO3 expression (Fig. 2a). Gene ontology analysis of affected genes showed significantly enriched biological processes (Supplementary Fig. 1d); we depicted the expression pattern of selected genes in these processes (Fig. 2b).

To validate the results, we used RT-PCR and/or western blot to correlate changes in RNA and protein expression. We selected 
$K L F 3$, involved in proliferation, development, and differentiation [33], and WDR33, identified by its role in $3^{\prime}$ RNA processing [34, 35]. For both, we confirmed alterations in RNA expression; DIDO3 $\triangle E 16$ ESC preferentially express the longer KLF3 isoform (Supplementary Fig. 2a, b) and a longer 3'UTR RNA region of WDR33 (Supplementary Fig. 2d, e). Analysis with available antibodies detected no alterations in protein expression in either case (Supplementary Fig. $2 c$, $f$, respectively).

Additional candidates were JAM2, expressed in ESC [36] and implicated in cell polarization [37], as is DIDO [27, 28], and CARM1, identified in early developmental differentiation [38]. RNA expression of the large JAM2 isoform was increased (Fig. 2c, d), and surface protein expression in mutant was elevated ESC (Fig. 2e). For CARM1, we observed a RNA read-through at its termination region (Fig. 2f); this resulted in an almost complete absence of CARM1 protein in DIDO3 $\mathrm{E} 16 \mathrm{ESC}$, which was restored following HADIDO3 expression (Fig. 2g).

\section{POU5f1 transcriptional termination and regulation by DIDO}

The POU5f1 gene encodes OCT4, the main core component for ESC self-renewal [39-41]. ESC from DIDO3 $\Delta C T$ [27] and DIDO3 $\triangle \mathrm{E} 16$ have an OCT4 downregulation delay during in vitro differentiation. ChIP-seq data identified a HADIDO3 binding site of the POU5f1 3'UTR within the 2-kb regulatory region (Fig. 3a). We confirmed DIDO3 binding by quantitative PCR and found $2.5 \pm 1.2-$ fold ChIP enrichment when normalized to input levels. RT-PCR verified a read-through at transcription termination in the DIDO3 $\triangle$ E16 ESC (Fig. 3b). To study the potential influence of POU5f1 3'RNA extension on OCT4 protein persistence in DIDO3 $\triangle \mathrm{E} 16 \mathrm{ESC}$, we constructed two POU5f1 expression plasmids, one with WT $3^{\prime}$ UTR and one with the extended $3^{\prime}$ UTR, both HAtagged on the $5^{\prime}$ site to distinguish their recombinant HA-OCT4 products from endogenous OCT4 (Fig. 3c). After stable transfection into WT ESC, clones with similar expression levels were seeded without LIF and stimulated with retinoic acid to induce differentiation and OCT4 downregulation. Western blot analysis showed prolonged expression of HA-OCT4 bearing the long 3'UTR versus the WT $3^{\prime}$ UTR (Fig. 3d).

\section{DID03 binds mainly in $\mathbf{3}^{\prime}$ gene regions to chromatin, overlapping with RNA polymerase II, and associates with DHX9 and R-loops}

DIDO3 interacts with RNA pol II [28]. Intersection analysis of HADIDO3 ChIP-seq peaks (GEO: GSE85029) with RNA pol II peaks (GEO: GSE34520 [42]) showed a DIDO3 overlap with RNA pol II, especially with pS2 (phosphorylated at serine 2), of 66\% (Fig. 4a; Supplementary Table 4), which suggests cooperation in regulation [43]. RNA pol II pS2 is associated with transcription termination [44-46], as are R-loop dynamics [12]. High R-loop levels at the $3^{\prime}$ end of genes suggest an R-loop role in preventing transcriptional read-through into adjacent genes [47]. Including R-loop ChIP-seq peaks in ESC (GEO: GSE70189 [47]) to upper intersections (Supplementary Table 4 ) yielded $\sim 45 \%$ of DIDO3 peaks with simultaneous RNA pol II S2p and R-loop peaks (Supplementary Fig. 3a). More than $50 \%$ of these genes had these peaks at the $3^{\prime}$ UTR or within $3 \mathrm{~kb}$ downstream.

Genes related to RNA splicing, termination, elongation rate, and R-loop dynamics were identified by ChIP-seq and/or RNA-seq (Supplementary Table 5). We concentrated on DHX9, a helicase involved in R-loop suppression and transcription termination [48], that interacts with DIDO3 in MEF [29]. We performed coimmunoprecipitation experiments using anti-DHX9 antibody on lysates of ESC overexpressing HADIDO3, or the HA-N- or HA-Cterminal part of DIDO3, developed the western blot with anti-HA antibody, and found co-immunoprecipitation with whole DIDO3 and its $C$ terminus, but not with the $N$ terminus (Fig. $4 \mathrm{~b}$ ).

DHX9 is present in the DNA/RNA hybrid interactome [48]. We tested for DIDO3 at genomic sites enriched in these hybrids, using a

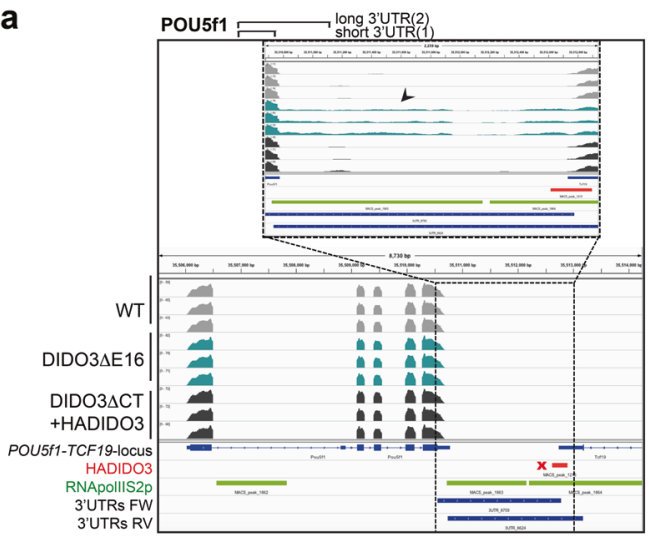

POU5f1

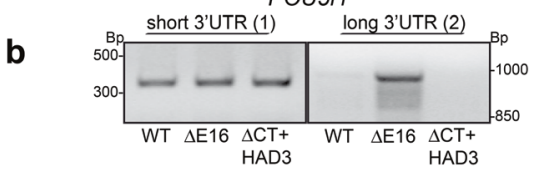

C

Plasmids:
\begin{tabular}{|l|l|l|l|l|l|}
\hline CAG HA & POU $5 f 1(\mathrm{ORF})$ & 3'UTR wt & IRES & puromycin \\
\hline CAG
\end{tabular}
\begin{tabular}{|l|l|l|l|l|}
\hline HA & POU $5 f 1(\mathrm{ORF})$ & 3'UTR long & IRES & puromycin \\
\hline
\end{tabular}

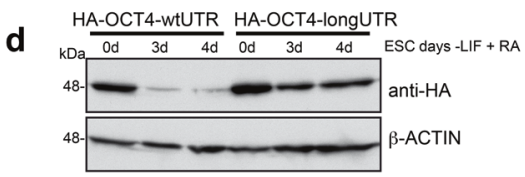

Fig. 3 DIDO transcriptional termination and regulation of POU5f1 RNA. a POU5f1 example gene: IGV image of the POU5f1 locus with parameters as in Fig. 2C, showing $3^{\prime}$ UTR read-through in the DIDO3 $\triangle E 16$ mutant. b Different abundance of POU5f1 short and long $3^{\prime}$ UTR (indicated in a) confirmed in WT, DIDO3 $\triangle E 16$, and DIDO3 $\triangle$ CT+HADIDO3 RNA as tested by RT-PCR. c Scheme of expression plasmids: introducing $5^{\prime} \mathrm{HA}$-tag sequences and short or long $3^{\prime} U T R$ to the open reading frame (ORF) of POU5f1 DNA. d Western blot analysis of lysates from ESC and embryonic bodies at d3 and d4 after LIF withdrawal plus retinoic acid from WT ESC transfected with (plasmids as in c), developed with anti-HA antibody; $\beta$-ACTIN was used as loading control.

the $\$ 9.6 \mathrm{mAb}$ to detect R-loops, as it recognizes DNA/RNA hybrids. We refer to its signal as R-loops (albeit aware that not necessarily all stable DNA/RNA hybrids in the genome are limited to R-loops). Sonicated chromatin of nuclear extracts from WT and DIDO3 $\triangle E 16$ ESC was immunoprecipitated with mAb S9.6. Western blot was developed with anti-DIDO and -DHX9 antibodies, and both coimmunoprecipitated with R-loops (Fig. 4c). We reduced DHX9 protein levels using siRNA and tested for DIDO3-sensitive transcription termination by RT-PCR, focusing on the prolonged $3^{\prime}$ UTR expression of POU5F1 as a read-through indicator. We found further increases in read-through events in siDHX9-treated mutant compared to control siRNA-treated ESC. A faint band was now detected in siDHX9-treated WT ESC, indicating read-through events (Fig. 4d). No influence was observed on the abolished CARM1 levels in mutant ESC, but treated WT ESC now also showed reduced CARM1 expression (Fig. 4e). Both results suggested that DHX9 function is necessary for correct transcription termination.

\section{DID03AE16 ESC have more R-loops and show signs of replication stress}

We measured R-loop levels in genomic DNA from WT and DIDO3 $\triangle \mathrm{E} 16$ cells in slot-blot experiments before and after 

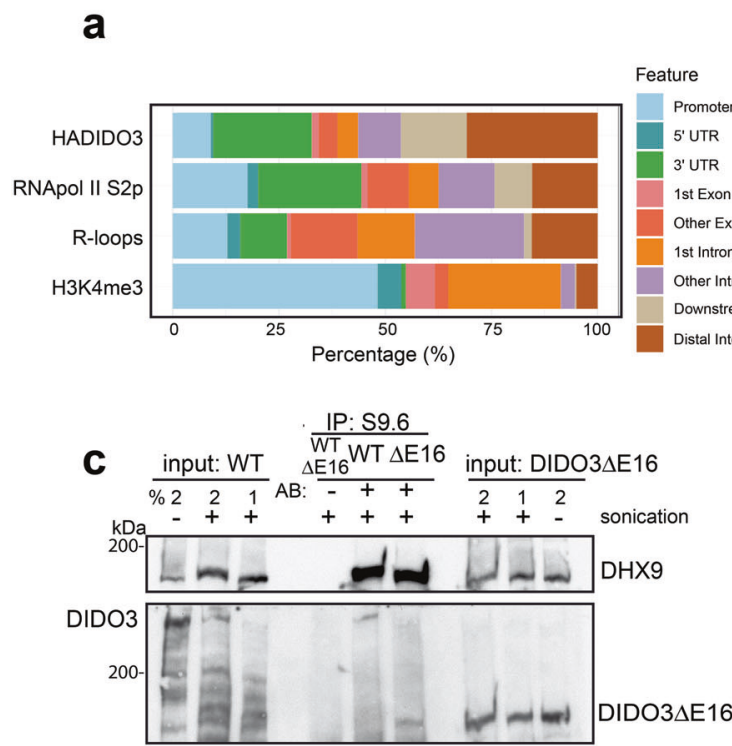

b

b
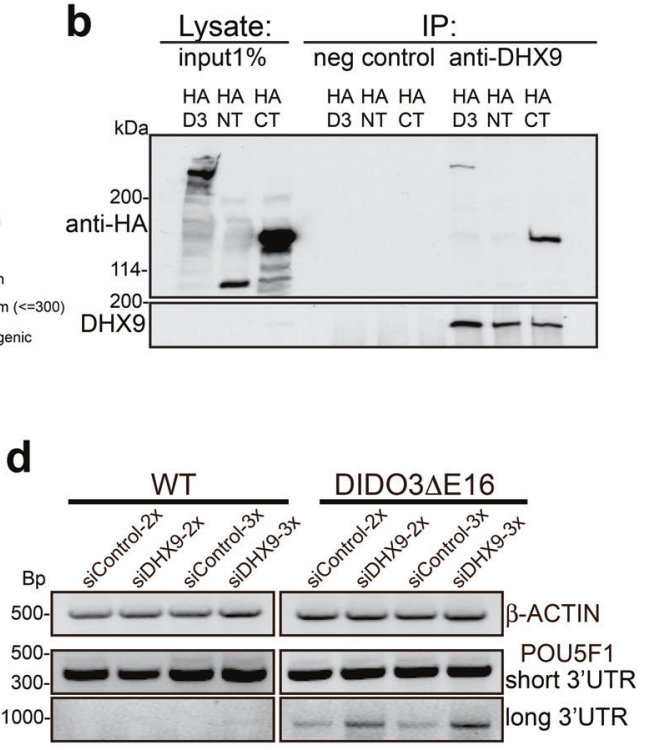

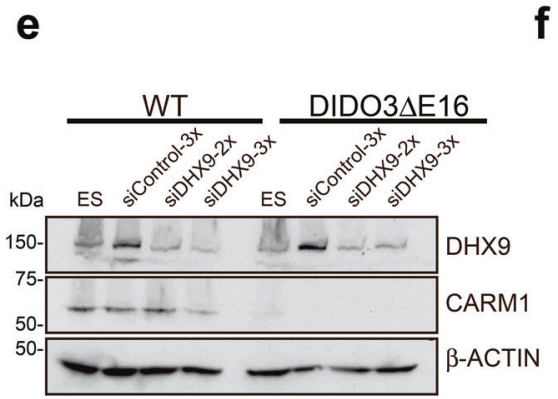

g

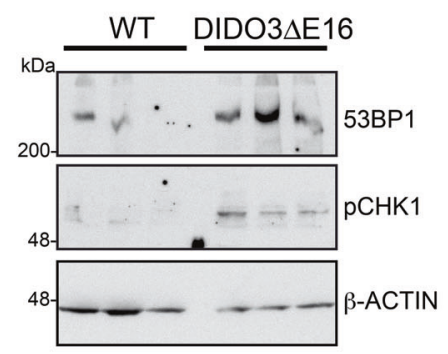

f

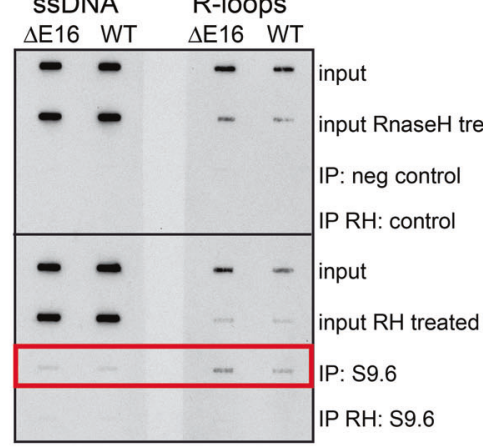

h

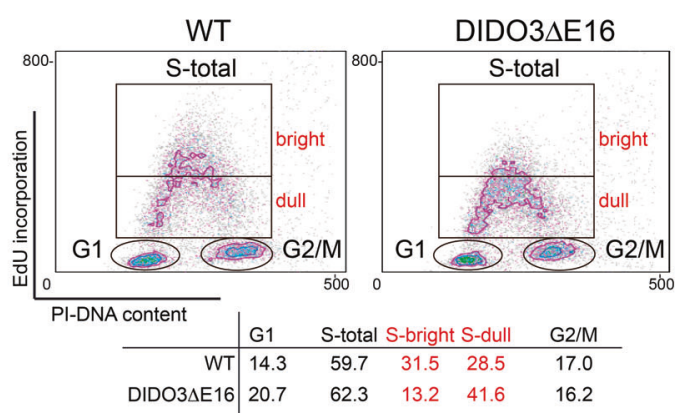

Fig. 4 Coexistence of DIDO3, RNA pol II, DHX9, and R-loops, and alterations in DIDO3 $\triangle E 16$ mutant ESC. a BED peak files were imported to RStudio and annotated using the R/Bioconductor package ChIPseeker. Peak annotations are depicted as a percentage for HADIDO3, RNA pol II S2p, R-loops, and H3K4me3 (histone 3 trimethylated on lysine 4). b Co-immunoprecipitation of HA-tagged DIDO3, -common N-terminal region, or -DIDO3-exon16-specific C-terminal part (for constructs see [28]), and DHX9 helicase. c Co-immunoprecipitation of DIDO3 or DIDO3 $\Delta$ E16 proteins and DHX9 helicase at R-loops precipitated with the S9.6 mAb, from sonicated chromatin of WT or DIDO3 $\Delta \mathrm{E} 16 \mathrm{ESC}$. d Abundance of POU5f1 short and long 3'UTR after two or three applications of siDHX9 or siControl in WT and DIDO3 $\triangle$ E16 ESC; $\beta$-ACTIN was used as control for equal RNA amounts. e Western blot analysis of DHX9 and CARM1 expression in WT and DIDO3 $\Delta$ E16 ESC after two or three applications of siDHX9 or siControl; $\beta$-ACTIN was used as loading control. $\mathbf{f}$ Left: representative example of slot-blot analysis of restriction enzyme-digested genomic DNA, before and after immunoprecipitation with S9.6 mAb, alone or treated with RNaseH1 from WT or DIDO3 $\Delta$ E16 ESC. Probes were used in duplicate; the first was developed with anti-ssDNA mAb and the second with anti-R-loop mAb S9.6. Right: quantification of slot-blot bands normalized to ssDNA values with ImageJ. Bars represent mean \pm SEM. Statistical analysis was done with twotailed Student's $t$-test, ${ }^{* *} P \leq 0.01 ;{ }^{*} P \leq 0.05$; DIDO3 $\Delta \mathrm{E} 16, n=3 ; \mathrm{WT}, n=3$. g Western blot analysis of total lysates from WT and DIDO3 $\Delta \mathrm{E} 16 \mathrm{ESC}$ developed with anti-53BP1 and anti-phosphorylated CHK1 (pCHK1) antibodies; $\beta$-ACTIN was used as loading control. $\mathbf{h}$ Contour density plot of WT and DIDO3 $\triangle$ E16 ESC after a 30-min EdU pulse, showing EdU incorporation versus DNA content. The percentages of events in cytometric gates defining different phases of the cell cycle are depicted. 
immunoprecipitation with the S9.6 mAb. S9.6 immunoreactivity was significantly higher in mutant versus WT samples (Fig. 4f), suggesting altered R-loop dynamics in mutant cells. Control DIDO $3 \triangle \mathrm{E} 16$ and WT genomic DNA treated with RNases of different substrate preference showed signal reduction only for RNaseH1 (Supplementary Fig. 3b). qPCR of the DRIP (DNA/RNA IP) probes showed abundant amplification of CARM1 and POU5f1 3' gene regions, confirming $\mathrm{R}$-loop presence in these regions. SOD3, a gene not expressed in ESC with no R-loops, was the negative control (Supplementary Fig. 3c).

To test the influence of ectopic expression of mouse RNaseH1 on R-loops in DIDO3-dependent transcription termination, we used two distinct HA-tagged RNaseH1 plasmids in transient or stable transfections. We detected protein expression with anti-HA antibody in western blot (Supplementary Fig. 3d), but no alterations in transcription termination as determined by RT-PCR (Supplementary Fig. 3e).

As increased R-loop levels can provoke genomic instability through DNA breaks and conflicts with the replication machinery, we tested for cell stress-associated proteins $[20,21]$ such as ATR/ CHK1 signaling by CHK1 phosphorylation (pCHK1) $[49,50]$, or proteins indicative of stress such as 53BP1 [51]. We found pCHK1 only in DIDO3 $3 \mathrm{E} 16$ cell lysates, with larger amounts of 53BP1 than in WT lysates (Fig. 4g), indicating cell stress in the mutant ESC. As replication stress leads ultimately to impaired DNA synthesis, we tested EdU (5-ethynyl-2'deoxyuridine) incorporation in asynchronized ESC. Although percentages of WT and mutant ESC in S-phase were comparable, mutant ESC incorporated lower EdU levels (Fig. 4h). Serum-starved mutant ESC enriched in G1-phase similarly maintained lower EdU levels and showed delayed S-phase re-entry compared to WT ESC (Supplementary Fig. 3f).

\section{DID03 C- but not N-terminal deletion leads to higher R-loop levels and replication stress in MEF}

We obtained d13.5 MEF from mice heterozygous for the floxed and deleted allele; they were infected with Ad5CMVCre-virus (AdCre) to achieve homozygous deletion of exon16, confirmed by PCR and western blot.

DIDO3 $\triangle \mathrm{E} 16$ and WT primary MEF were labeled with the S9.6 $m A b$ to visualize R-loops, and with $\mathrm{\gamma H} 2 \mathrm{Ax}$ antibody to detect DNA damage. As AdCre infection already increased R-loop and $\mathrm{\gamma H} 2 \mathrm{Ax}$ levels in WT MEF, we quantified R-loops and DNA breaks in both MEF types after AdCre infection. We labeled MEF at $\mathrm{d} 2$ and $\mathrm{d} 8$ post infection. Compared to WT, DIDO3 $\triangle \mathrm{E} 16 \mathrm{MEF}$ showed persistent, increased R-loop and $\mathrm{\gamma H} 2 \mathrm{Ax}$ levels at both times (Fig. 5a). We used anti-53BP1 to detect replication stress as 53BP1positive nuclear bodies (NB) [51] and found increased 53BP1positive NB in DIDO3 $\triangle E 16$ compared to WT MEF (Fig. 5b); replication stress was increased at $\mathrm{d} 8$ in mutant MEF.

We also examined DIDO $\triangle \mathrm{NT}$ MEF in immunofluorescence experiments as above with S9.6, $\mathrm{yH} 2 \mathrm{Ax}$, and 53BP1 antibody staining, and found opposing results in DIDO $\triangle$ NT and DIDO $3 \Delta \mathrm{E} 16$ compared to WT MEF. R-loop levels in DIDO $\triangle$ NT were significantly lower than in WT MEF (Supplementary Fig. 4a), with $\mathrm{\gamma H} 2 \mathrm{Ax}$ (Supplementary Fig. 4a) and 53BP1 levels similar to WT (Supplementary Fig. 4b).

\section{DID03-exon16 is necessary for somatic cell reprogramming}

To determine the influence on somatic reprogramming, we crossed DIDO3-exon16 floxed mice to transgenic mice with doxycycline-inducible expression of the reprogramming genes Tg(tetO-POU5f1,SOX2,KLF4,MYC)1Srn [52]. Day 13.5 MEF were AdCre-infected for homozygous deletion of exon16, and doxycycline-treated to induce expression of the four circuit stem cell factors necessary for somatic reprogramming [3] (Fig. 6a). PCR and western blot confirmed deletion efficiency before induction (Supplementary Fig. 5a, b). We obtained iPSC from WT MEF, but
DIDO3 $\triangle E 16$ MEF showed severely reduced reprogramming efficiency. Although some colonies stained for the early pluripotency marker alkaline phosphatase (AP) (Fig. 6b), colonies tested for DIDO3 expression showed that half had escaped AdCre deletion and still bore the floxed DIDO3 allele. In eight independently established DIDO3 $\triangle \mathrm{E} 16 \mathrm{MEF}$ samples, reprogramming was almost abolished (Fig. 6c).

Like DIDO3 $\triangle \mathrm{E} 16 \mathrm{ESC}$, the few iPSC generated from mutant MEF had a correct pluripotency network (Supplementary Fig. 5c), but did not downregulate OCT4 at differentiation onset (Supplementary Fig. 5d).

DIDO3 $\Delta$ E16 mutants differ from the DIDO $\Delta$ NT mutants which, despite cell cycle and genomic stability problems [24, 25] and splicing defects [29], show neither embryonic lethality [26] nor ESC differentiation defects. For somatic reprogramming, we tested doxycycline-treated MEF from DIDO $\triangle$ NT crossed to reprogrammable OKSM mice, and obtained fully reprogrammed iPSC (Fig. 6d, e, f). Like DIDO $\triangle N T$ ESC, established iPSC were bona fide iPSC with completely normal stemness characteristics (Supplementary Fig. 6a) and able to differentiate into cells of all three germ layers (Supplementary Fig. 6b).

\section{Immortalization of DIDO3AE16 MEF rescues somatic cell reprogramming capacity}

We tested whether immortalizing primary MEF by E6/E7 transfection could rescue impaired reprogramming in DIDO3 $\triangle E 16 \mathrm{MEF}$. Immortalized WT and DIDO3 $\triangle \mathrm{E} 16 \mathrm{MEF}$ [29] were infected with a mixture of the four retroviruses expressing each of the OKSM transcription factors to induce reprogramming, or with GFPexpressing retrovirus as a negative control for reprogramming and positive control for infection efficiency (Fig. 7a). In all experiments, infection efficiency measured by FACS was $>80 \%$ in both genotypes. After 10 days, AP staining experiments and quantification of reprogramming efficiency (Fig. 7b) showed restored DIDO3 $\triangle \mathrm{E} 16$ reprogramming, with a significant increase compared to immortalized WT MEF (Fig. 7c).

Our results support a model in which DIDO3 interacts and collaborates with DHX9 to regulate R-loops at RNA pol II transcription termination sites (TTS) (Fig. 7d). DIDO3-exon16 deletion leads to altered DHX9 function, induces defects in RNA termination seen as read-throughs, and results in more stable Rloops. All these factors contribute to genomic instability, DNA damage, and replication stress, which in turn abolish stem cell differentiation and somatic cell reprogramming (Fig. 7e).

\section{DISCUSSION}

We previously identified the DIDO locus that participates in early embryonic development and ESC differentiation; here we postulate an underlying molecular mechanism and an additional DIDO role in somatic cell reprogramming.

The DIDO gene is stemness-related, and C-terminal deletion leads to embryonic lethality and differentiation defects [27, 28]; in contrast, mice with DIDO N-terminal truncation survive [26]. Here we confirm embryonic lethality of mice with homozygous deletion of the conditional targeted DIDO3-exon16, and differentiation defects in their ESC. We crossed DIDO mutant mice with the transgene OKSM-4F mice [52] and used reprogrammable OKSMMEF from WT, DIDO $\triangle N T$, and DIDO $3 \Delta \mathrm{E} 16$ mutants. At difference from WT and DIDO $\triangle N T$ MEF, which reprogram with comparable efficiency, DIDO3 $\triangle \mathrm{E} 16 \mathrm{MEF}$ were reprogramming-incompetent.

Whole transcriptome analysis of mutant ESC revealed two principal defects; RNA alternative splicing (as in e.g., DIDO1, KLF3, and JAM2) and RNA termination defects (e.g., WDR33, CARM1, and POU5f1). For CARM1, which methylates several splicing factors and enhances exon skipping [53], protein expression was decreased. POU5f1 is of particular interest, given its role in stem cell maintenance and differentiation $[39,54]$. We observed that 
a

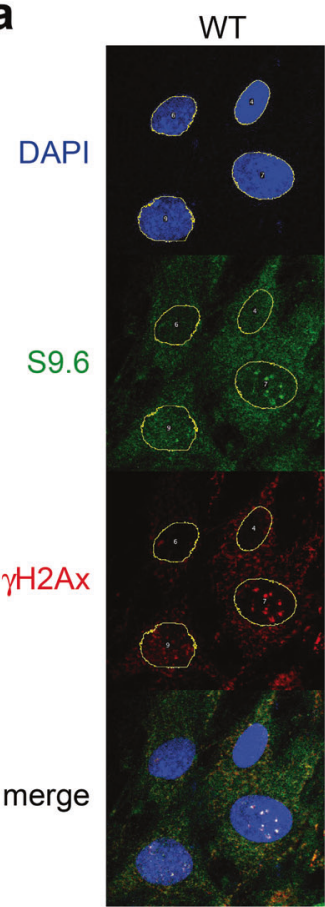
DIDO3 $3 \mathrm{E} 16$
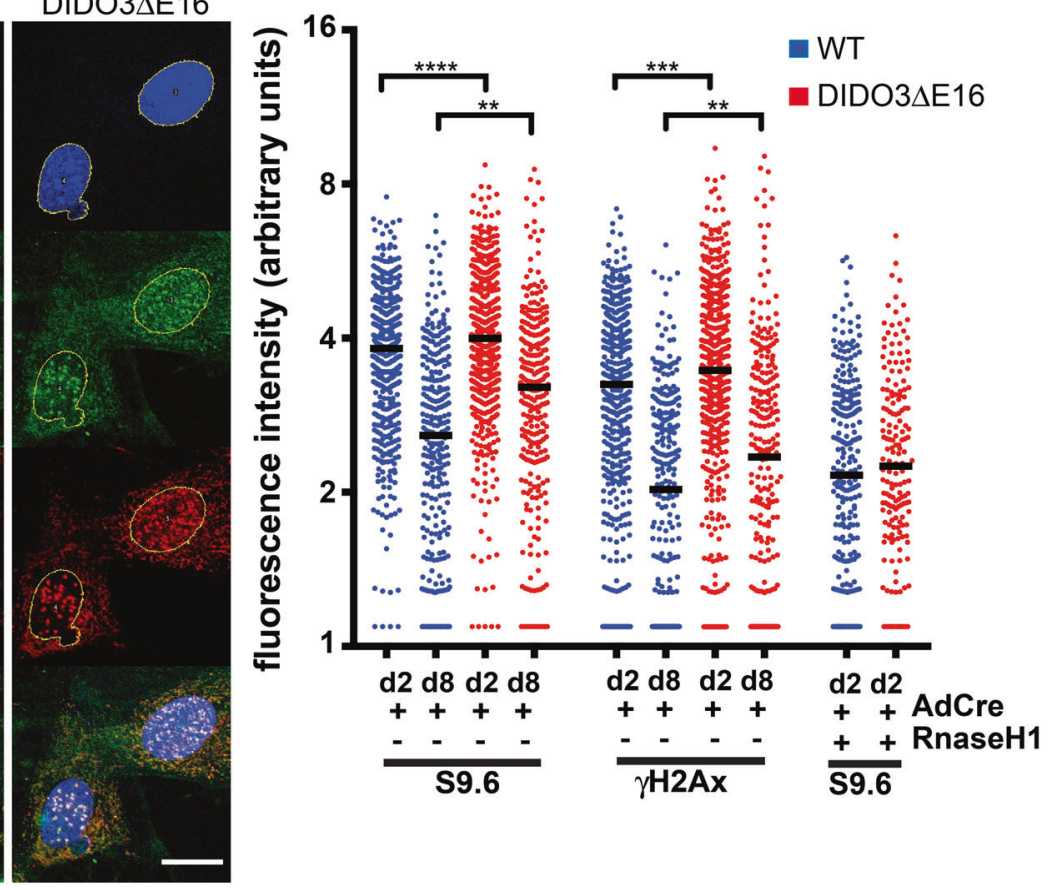

b
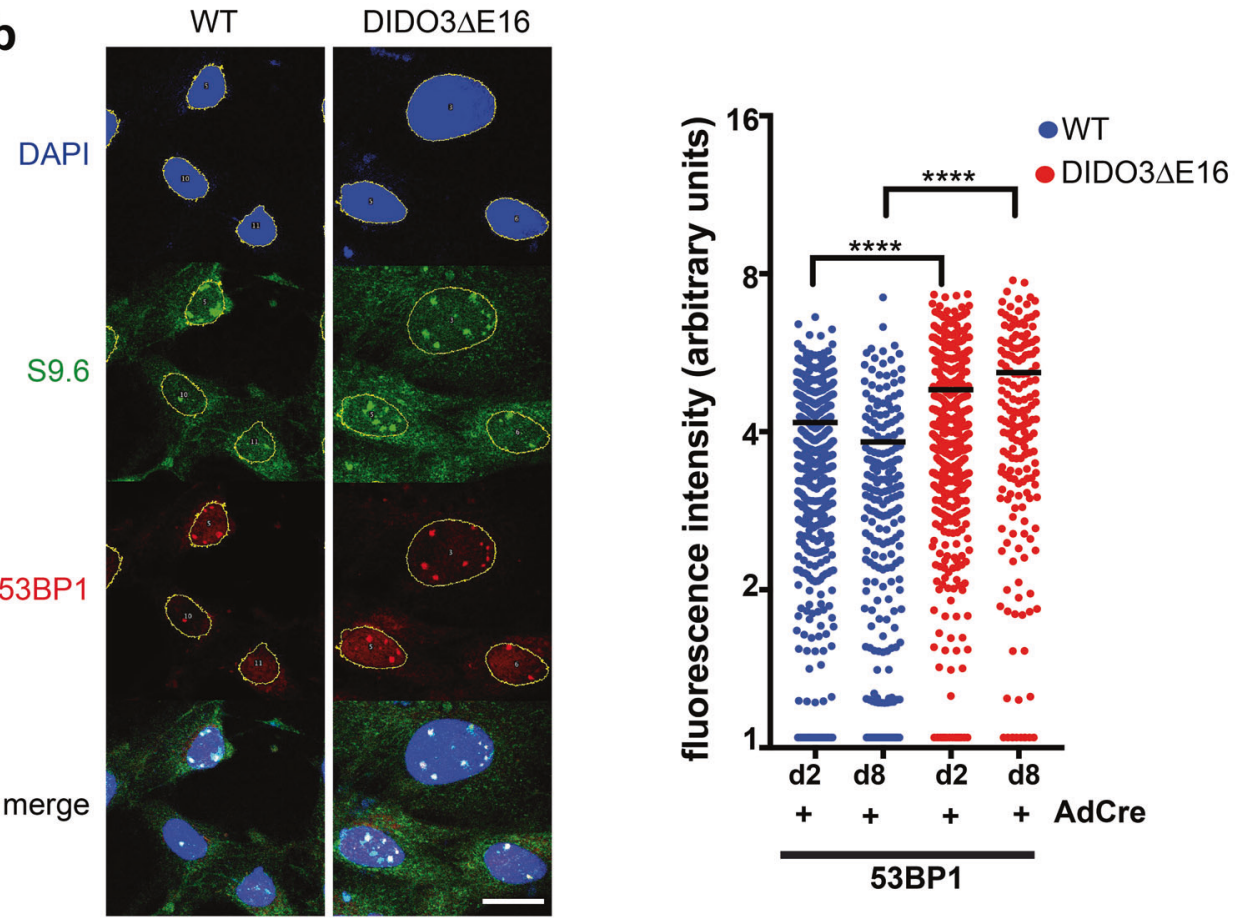

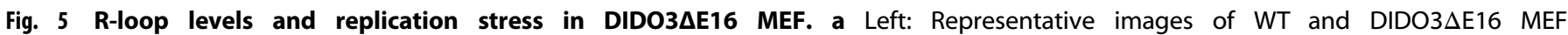
immunofluorescence after AdCre infection, using DAPI to stain nucleus (blue), S9.6 mAb to stain R-loops (green) and DNA damageindicating antibody $\gamma-\mathrm{H} 2 \mathrm{Ax}$ (red). Yellow circles depict nucleus corresponding to DAPI-positive staining and as region of interest (ROI) for ImageJ quantification of fluorescence intensity. Bar $=25 \mu \mathrm{m}$. Right: fluorescence intensity of S9.6 mAb for R-loops and $\gamma$-H2Ax for DNA damage was quantified in the nuclear region of WT and DIDO3 $\triangle$ E16 MEF after AdCre infection at indicated times. At least 170 cells were analyzed from three different experiments. Specificity for S9.6 mAb was controlled after RNaseH1 treatment. Scatter dot plot with median is shown. Statistical analysis was performed with the one-way ANOVA test, ${ }^{* * * *} P<0.0001 ;{ }^{* * *} P<0.001 ;{ }^{* *} P \leq 0.01$. b Left: representative images of WT and DIDO3 $\triangle E 16$ MEF immunofluorescence after AdCre infection, with DAPI stain to indicate nucleus (blue), S9.6 mAb for R-loops (green), and replication stress-indicating antibody 53BP1 (red). Yellow circles depict the nucleus corresponding to DAPI-positive staining and as region of interest (ROI) for ImageJ quantification of fluorescence intensity. Bar $=25 \mu \mathrm{m}$. Right: quantification of $53 \mathrm{BP} 1$ fluorescence intensity to detect replication stress in the nucleus of WT AdCre versus DIDO3 $\Delta \mathrm{E} 16 \mathrm{AdCre}$ at $\mathrm{d} 2$ and $\mathrm{d} 8$. At least 170 cells were analyzed from three different experiments. Scatter dot plot with median is shown. Statistical analysis was performed with the one-way ANOVA test, ${ }^{* * * *} P<0.0001$. 
a DIDO3 $\triangle E 16$ mutant MEF

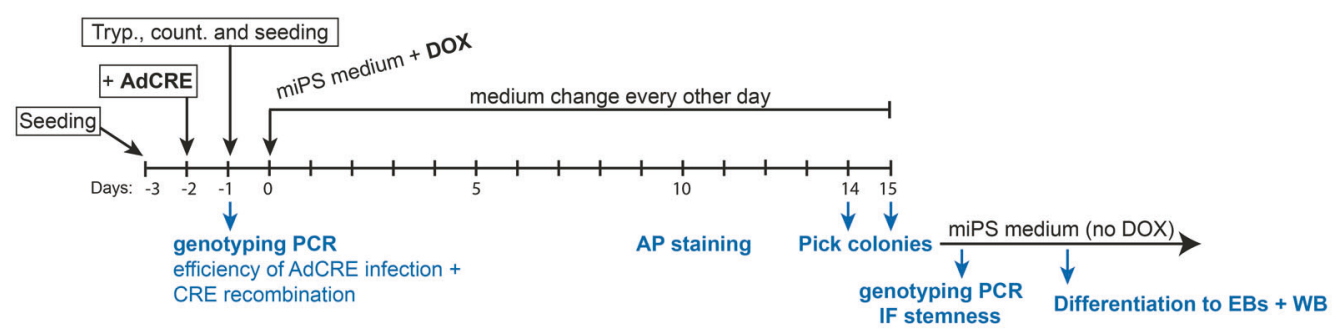

b

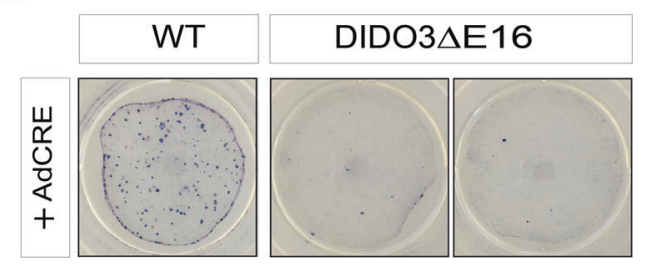

C

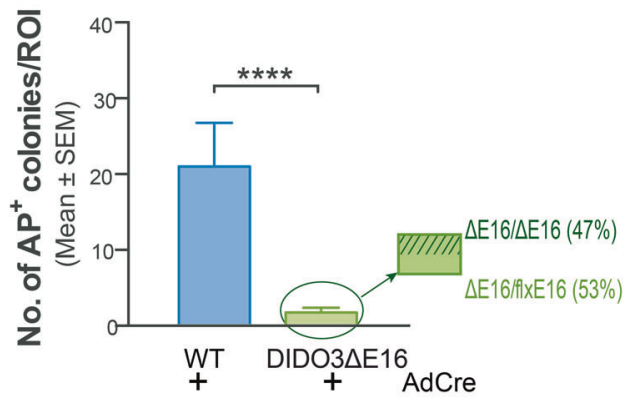

\section{d DIDOANT mutant MEF}

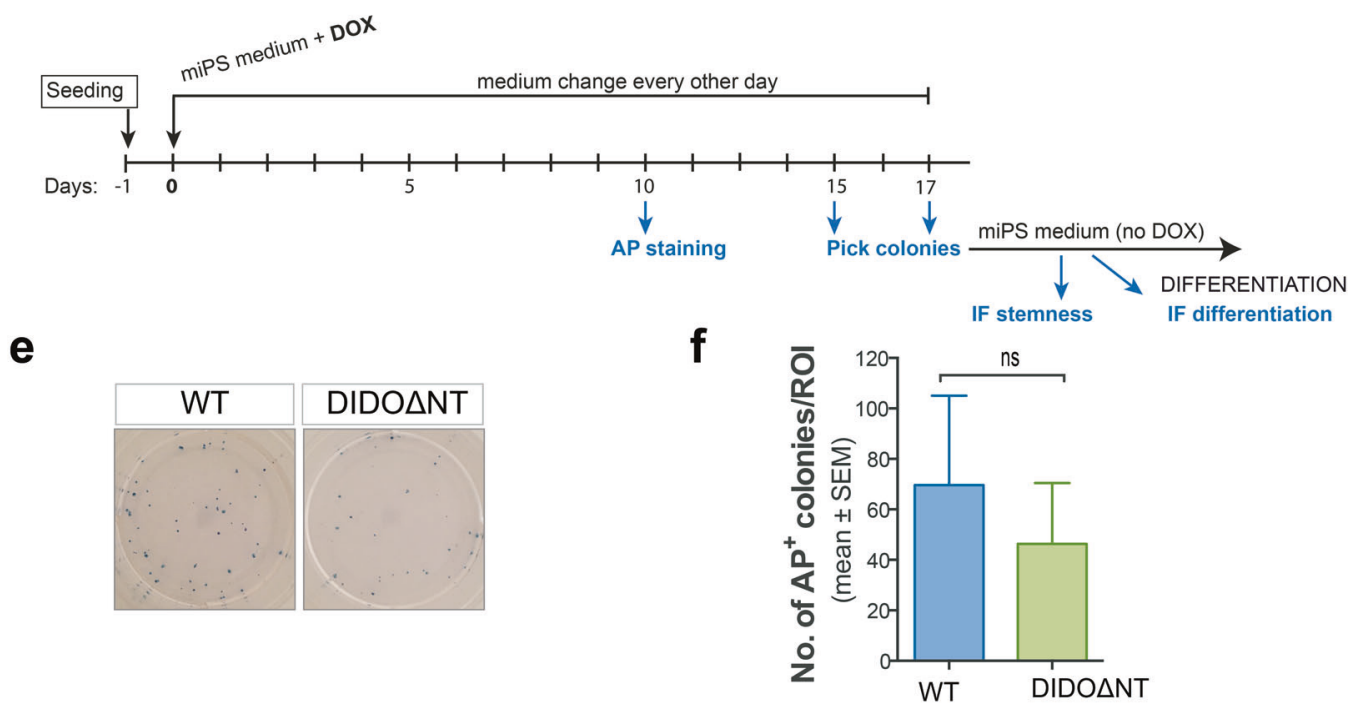

Fig. 6 Somatic reprogramming requires DIDO3-exon16 but not the $\mathrm{N}$-terminal region to induce pluripotent stem cells. a Scheme for experimental onset and reprogramming procedures for DIDO3 $\Delta$ E16/4F-MEF. Tryp trypsinization, DOX doxycycline addition, AP alkaline phosphatase staining. b Image of representative wells after staining for AP-positive colonies as a pluripotency marker following reprogramming of WT and DIDO3 $\Delta \mathrm{E} 16 \mathrm{MEF}$ after AdCre infection. c Quantification of reprogramming ability of DIDO3 $\Delta \mathrm{E} 16 / 4 \mathrm{~F}-\mathrm{MEF}$ versus WT/4F-MEF after AdCre infection, as determined by AP-positive colonies. DIDO3 $\Delta \mathrm{E} 16, n=8$; WT $n=8$; bars indicate mean \pm SEM. Statistical analysis was performed with two-tailed Student's $t$-test, ${ }^{* * * *} P<0.0001$. Percentage of genotypes in iPS homozygous for DIDO3 $\triangle E 16 / D I D O 3 \triangle E 16$ or heterozygous for DIDO3 $\triangle E 16 / D I D O 3$ floxedE16 was determined by PCR. d Scheme of experimental onset and DIDO $\Delta \mathrm{NT} / 4 \mathrm{~F}-\mathrm{MEF}$ reprogramming procedures. e Staining for AP-positive colonies as a pluripotency marker after WT and DIDO $\triangle N T$ MEF reprogramming. f Quantification as in (c) for DIDO $\Delta$ NT/4F-MEF $(n=3)$ and WT/4F-MEF $(n=3)$; bars represent mean \pm SEM. Statistical analysis was performed with two-tailed Student's $t$-test and showed no significant differences (ns).

aberrantly extended $3^{\prime}$ UTR resulted in a protein with impaired downregulation at the onset of differentiation.

Our data show that although changes in the $3^{\prime}$ UTRs do not alter protein structure, 3'UTR have pleiotropic regulatory functions [55]. Inclusion of ChIP-seq data identified DIDO3 binding sites at the $3^{\prime}$ gene regions. These DIDO sites coincide with RNA pol II S2p, whose binding at $3^{\prime}$ gene ends is implicated in RNA termination by interaction with complexes involved in splicing, cleavage, and polyadenylation [56] and with R-loops, which can pause RNA pol II at termination sites [12, 56-58]. Combined analyses showed that all convergent genes and nearly half of coorientated genes had RNA anomalies, suggesting a crucial role for DIDO3 on R-loops at gene-rich regions in the genome. These results might define a mechanism by which DIDO regulates $\mathrm{R}$ loops, whose presence impedes transcriptional read-through into neighboring genes [47]. Our data adjust well with the plant BORDER (BDR) protein family, whose domain organization resembles that of DIDO. They act similarly as insulator proteins, 
a

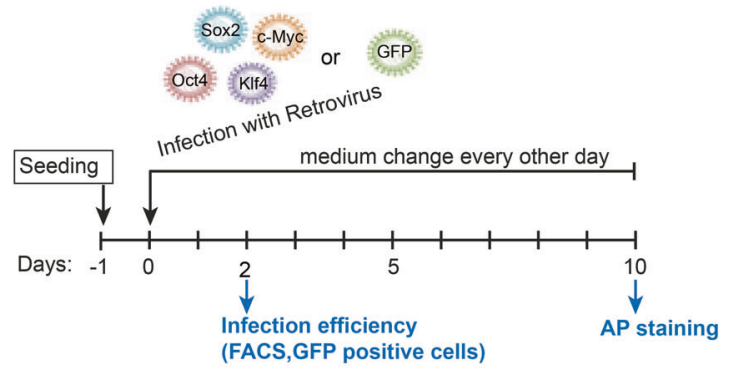

b

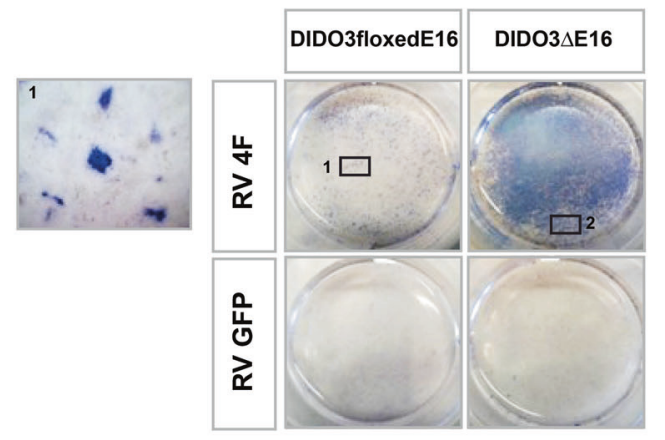

d

WT

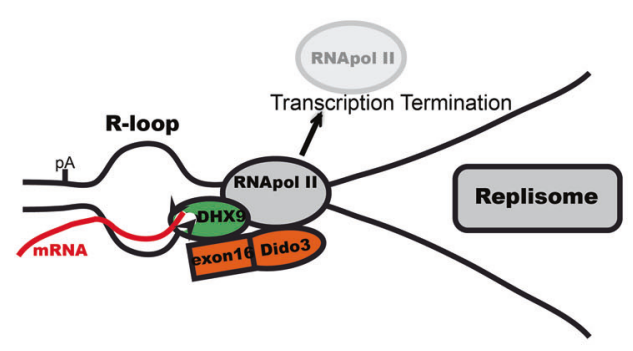

C

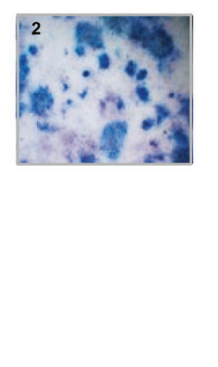

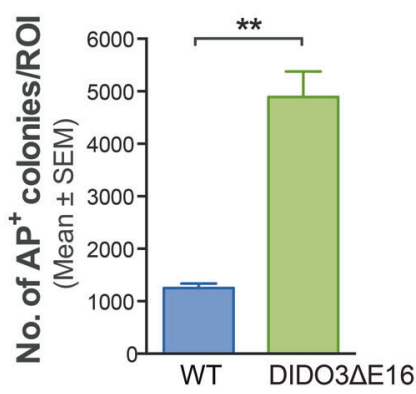

e

Dido3 $\triangle E 16$

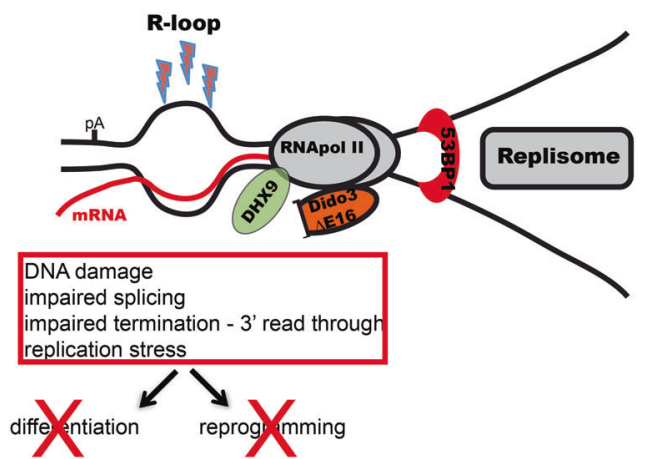

Fig. 7 Recovery of reprogramming capacity in immortalized DIDO3DE16 MEF, and model for transcription termination in WT and DIDO3AE16 cells. a Scheme for experimental onset and procedures for reprogramming immortalized DIDO3 3 E16. b Top: images of representative wells of AP-positive colonies as a pluripotency marker after infection with OKSM retroviruses, from reprogrammed parental DIDO3floxedE16 before Cre deletion and from DIDO3 $\triangle$ E16 MEF. Bottom: control wells with GFP-retrovirus infection. c Quantification to determine AP-positive colonies; bars represent mean \pm SEM. Statistical analysis using two-tailed Student's $t$-test showed significant differences ${ }^{* *} P \leq 0.01$. d In WT cells, DHX9 binds to RNA pol II and DIDO3 at termination sites, RNA pol II terminates RNA transcription, DHX9 resolves R-loops, and RNA pol II dissociates from DNA. e In DIDO3 $\mathrm{E} 16$ cells, DHX9 function is impaired, R-loops persist, RNA pol II continues reading, DNA damage occurs on the single-stranded DNA, and transcription-replication conflicts provoke cell stress. All these effects abolish differentiation and reprogramming.

preventing transcriptional interference into closely located genes; BDR3 shows a genome binding profile especially similar to DIDO3, with high occupancy at TTS [59].

Regulation of R-loop levels is critical, and misregulation causes DNA damage $[13,21,60]$, blocks replication forks, and leads to replication stress $[12,15,20]$. DNA damage is observed in both $\mathrm{N}$ - and C-terminal deletion DIDO mutants [24, 25, 27]. In contrast to DIDO $\Delta$ NT cells, both DIDO3 $\triangle$ E16 ESC and MEF showed increased R-loop formation.

We found DHX9 association to DIDO3 protein via its DIDO3specific exon16-encoded domain, and both co-localize with Rloops. The DHX9 helicase is involved in transcription termination [48], and is implicated in physiological as well as pathological Rloop formation, especially when splicing alterations are present [61].
Although it remains unclear whether RNA termination defects in DIDO3 $\triangle$ E16 ESC are due to impaired unwinding of DNA/RNA hybrids or of dsRNA, we confirmed that DHX9 is needed for correct transcription termination. Since additional DHX9 functions are described [62], including in DNA repair [63], a process implicated in somatic cell reprogramming [64], we cannot exclude that dysregulation of some other functions contribute to reduced reprogramming efficiency in DIDO3 $\triangle \mathrm{E} 16 \mathrm{MEF}$.

The results of RNaseH1 overexpression in vivo on DIDO3dependent termination read-throughs were explainable, as it is exactly the difference between mapping R-loops with the S9.6 $\mathrm{mAb}$ or by enzymatically inactive $\mathrm{RNaseH} 1$ [65]. RNaseH1 barely maps to TTS, and the existence of RNaseH1-resistant R-loops has been discussed [66]; in vivo, other enzymes very likely play a role. 
RNaseH 2 could be a candidate, and topoisomerase 1 was recently linked to replication stress at R-loop-enriched TTS [67].

Immortalized DIDO $\Delta$ NT and DIDO3 $\triangle \mathrm{E} 16$ MEF have splicing alterations based on altered SFPQ association [29]. Although these splicing defects are known to increase R-loops [61], the DIDO $\Delta$ NT mutation with intact DIDO3-exon16 showed no increase in R-loop levels and maintained R-loop regulation capacity. In DIDO $3 \Delta \mathrm{E} 16$, where SFPQ and DHX9 binding are affected, both could nonetheless contribute to elevated R-loop levels.

High R-loop levels can disturb replication progression $[13,15,19,60]$ and lead to replication stress as defined by 53BP1 expression [51]. We detected stress in DIDO3 $\triangle \mathrm{E} 16 \mathrm{ESC}$ and $\mathrm{MEF}$, and showed that replication stress ultimately impairs DNA synthesis in DIDO3 $\triangle E 16$ ESC. We detected replication stress exclusively in DIDO3 $\triangle \mathrm{E} 16$ mutants, but neither in DIDO $\Delta$ NT nor in WT cells, which illustrates the importance of DIDO3 in regulating RNA metabolism.

MEF immortalization overcomes cell damage checkpoints; in DIDO3 $\triangle E 16$ MEF, replicative stress could be a form of cell damage that contributes to their decreased reprogramming capacity, and E6/E7 immortalization helps restore it.

The importance of R-loop biology has grown in recent years; new insights, their complexity, and available tools have been discussed [68]. Questions remain regarding the DIDO $\triangle \mathrm{E} 16$ phenotype, including the players involved and the precise mechanism of R-loop involvement. Our results nonetheless allow us to postulate a central role for DIDO3 in regulating RNA metabolism, and that the DIDO3-specific exon16 is essential for this function. Its deletion triggers defects in RNA splicing and termination, and impedes dissolution of the increased R-loops, both in association with impaired DHX9 helicase recruitment through the DIDO3-exon16-encoded protein domain. Cells suffer genomic instability, DNA damage, and replication stress; ESC thus fails to undergo differentiation and MEF to undergo somatic cell reprogramming.

\section{MATERIALS AND METHODS \\ Construct of a conditional allele with floxed exon 16 of the Dido gene}

Heterozygous mice with DIDO3-exon16 flanked by LoxP sites were generated by Ozgene Pty Ltd (Bentley, AU). In brief, a LoxP site was inserted at the $3^{\prime}$ end of DIDO intron 15. A neomycin selection cassette (neo, encoding amino $3^{\prime}$-glycosyl phosphotransferase) was inserted downstream of DIDO3-exon16, flanked with flipase recombination target (FRT) sites and followed by another LoxP site and a sequence reproducing the splice acceptor of DIDO3-exon16.

The linearized targeting vector was electroporated into C57BL/6-derived Bruce4 ES cells. Successful homologous recombination was identified by Southern blot screening of antibiotic-resistant ESC colonies. After blastocyst microinjection, chimeric offspring were crossed to C57BL/6 J mice to yield heterozygous DIDO-tm3Cmar mice, which were transferred to our animal facility. For Cre recombination we used $\mathrm{Tg}(\mathrm{SO} 2 \mathrm{C}-\mathrm{Cre}) 1 \mathrm{Amc}$ mice. To obtain reprogrammable MEF, we crossed these mice further to $\mathrm{Tg}$ (tetOPOU5f1,SOX2,KLF4,MYC)1Srn mice.

\section{Cell culture}

ESC were cultured in KO-DMEM (Gibco, ThermoFisher) supplemented with $20 \%$ fetal calf serum, GlutaMAX (Gibco, ThermoFisher), non-essential amino acids, 2-mercaptoethanol, antibiotics, and murine leukemia inhibitory factor (LIF, Millipore) on a layer of mitomycin C-treated mouse embryonic fibroblasts (MEF) or gelatinized tissue culture plates. MEF were cultured in the same medium without LIF supplement.

For stable transfectants, we used Lipofectamine 2000 (ThermoFisher) according the manufacturer's protocols; selection was performed with puromycin. To induce differentiation, ESC were cultured in MEF medium without LIF in low-adhesion plates.

All cell cultures were routinely tested for the absence of mycoplasma contamination.

\section{In vitro reprogramming of primary 4F-MEF}

For in vitro reprogramming of primary OKSM-inducible MEF, day E13.5 cells were seeded at a density of $5.5 \times 10^{5}$ cells $/ \mathrm{cm}^{2}$ in MEF medium in $0.1 \%$ gelatin-coated 6-well plates. After $24 \mathrm{~h}$, medium was changed to iPS medium (the same as ESC media with doxycycline $(1 \mu \mathrm{g} / \mathrm{mL})$, Sigma). In the case of the DIDO3 $\triangle E 16$ heterozygous mutant and wt MEF, both were infected with Ad5CMV-Cre virus (Viral Vector Core Facility, University of lowa, lowa City, IA) at a multiplicity of infection (MOI) of 500, one day before starting doxycycline treatment.

Medium was changed every other day until cells were used for alkaline phosphatase (AP) assays (10-14 days after initiation of doxycycline treatment) or colonies were picked (13-15 days after initiation of doxycycline treatment) and cultured for further characterization.

For in vitro reprogramming of E6/E7 immortalized wt and DIDO3 $\Delta E 16$ MEF [29], cells were infected with the mixture of the four retroviruses bearing the plasmids encoding OKSM, or with GFP, and cultured in normal ESC medium until day 10, when AP staining was carried out.

We monitored cells for alkaline phosphatase (AP staining kit AB-0300; Sigma) as a first sign of pluripotency. Images of plate wells were analyzed with ImageJ software (NIH) by Analyse Particles (note that regions of interest (ROI) were distinct in experiments with primary or immortalized MEF).

\section{Cell cycle analysis and EdU incorporation}

ESC were labeled with $10 \mu \mathrm{M}$ EdU (5-ethynyl-2'deoxyuridine; $30 \mathrm{~min}$ ), processed with the Click-iT Plus EdU Flow Cytometry Assay Kit (ThermoFisher) following the manufacturer's protocols, and then analyzed in a Beckman Coulter Flow Cytometer FC500. To enrich ESC in G1-phase, cells were cultured $(24 \mathrm{~h})$ in ESC medium with $1 \% \mathrm{FCS}$ and $20 \mathrm{ng} / \mathrm{ml} \mathrm{bFGF}$ (Invitrogen), and serum-released in normal ESC medium with 20\% FCS; $10 \mu \mathrm{M}$ EdU was then added for $30 \mathrm{~min}$.

\section{Knockdown and overexpression experiments}

Small interfering (si) RNA experiments were performed with ONTARGETplus SMARTpool specific for mouse DHX9 or, as negative control, with Non-targeting Pool (both from Dharmacon). Plasmids for mouse RNaseH1 overexpression, pCAGG-HARNaseH1-IRES-hygromycin, and Kozak-optimized plasmid were a generous gift from Dr. Thomas G. Fazzio [16]. In both cases, cells were transfected with Lipofectamine 2000 following the manufacturer's instructions.

\section{Protein analysis}

For immunofluorescence analyses (stemness and differentiation), cells were fixed in $4 \%$ paraformaldehyde, permeabilized, and blocked with $0.5 \%$ Triton X-100, $6 \%$ horse serum in TBS, stained with primary (overnight, $4^{\circ} \mathrm{C}$ ) and secondary antibodies ( $2 \mathrm{~h}, \mathrm{RT})$, and mounted in DAPI-containing medium.

For immunofluorescence with $\mathrm{59.6}, \mathrm{\gamma H} 2 \mathrm{Ax}$, and 53BP1 antibodies, cells were fixed in ice-cold methanol, permeabilized with $0.1 \%$ Triton $X-100$, and blocked in 5\% BSA/PBST. Negative control cells were treated with RNAseH (NEB) at $37^{\circ} \mathrm{C}$ overnight before blocking.

For confocal microscopy, we used a Zeiss laser scanning or an Olympus confocal microscope. Images were processed and quantified with ImageJ. Integrated density was calculated above defined thresholds, and the value for negative cells was set at less than the lowest measured value.

For flow cytometry analysis, cells were disaggregated with enzyme-free cell dissociation buffer (Invitrogen) and the surface was labeled with antiJam2 rat monoclonal antibody (R\&D Systems).

For co- and immunoprecipitation (IP) experiments, cell lysates were prepared in NETN buffer with protease inhibitors (Roche) and $1 \mathrm{mM} \mathrm{PMSF}$, incubated with specific antibodies $\left(4^{\circ} \mathrm{C}\right.$, overnight), followed by Protein A- or G1-loaded magnetic beads (Dynabeads, ThermoFisher; $4^{\circ} \mathrm{C}, 2 \mathrm{~h}$ ). Immunoprecipitates were washed six times, released from beads in sample buffer, and used for western blot.

For western blot, cell pellets were lysed in cell lysis buffer (Cell Signaling), $20-40 \mu \mathrm{g}$ protein solution was loaded for SDS-PAGE, then transferred to nitrocellulose membrane (Bio-Rad), and probed with the indicated antibodies.

Antibodies used are listed below.

\section{RNA and RT-PCR}

Total RNA was prepared with a SPLIT RNA extraction kit (Lexogen, Austria) according to the manufacturer's protocol, using $\sim 2.5 \times 10^{6}$ cells. RT-PCR 
amplifications were performed with a Verso One-step RT-PCR Kit (ThermoFisher), using $0.1 \mu \mathrm{g}$ RNA and specific primers for the amplified genes. Oligonucleotides are listed below.

\section{DRIP, slot blot, and qPCR}

For R-loop precipitation on chromatin, nuclear pellets were lysed in RIPA buffer containing $10 \%$ glycerol, protease inhibitor cocktail (Roche), and $1 \mathrm{mM}$ PMSF, sonicated 10 times $(10 \mathrm{~s}$ on, $30 \mathrm{~s}$ off) in a Bioruptor (Diagenode), and incubated with $\$ 9.6 \mathrm{mAb}$ coupled to Protein A magnetic beads (Dynabeads; $4^{\circ} \mathrm{C}$, overnight) in the presence of RNaseA $(10 \mathrm{ng} / \mathrm{ml})$, followed by SDS-PAGE and western blot as described above for IP.

For R-loop precipitation on DNA, we mainly followed the initial protocol of Ginno et al. [69] as further detailed by Sanz et al. [70], with some modifications. In brief, cell nuclear extracts were prepared and digested with Proteinase $\mathrm{K}\left(56^{\circ} \mathrm{C}\right.$, overnight), purified by phenol/ chloroform treatment, precipitated with ethanol and resuspended in TE buffer. DNA was digested overnight in the restriction enzyme cocktail, again purified, precipitated, and resuspended in TE buffer. Half the DNA was treated with RNaseH1 (NEB); input samples of both purified with PCR purification columns (Qiagen) were stored; DNA probes, treated and untreated, were diluted in binding buffer and precipitated overnight with S9.6 antibody coupled to Protein A-loaded magnetic Dynabeads. After washing with binding buffer, immunoprecipitates were eluted in TE buffer with SDS, digested with Proteinase $K$, and purified with the PCR purification kit (Qiagen).

Inputs and precipitates were validated in duplicate by slot blot analysis on positively charged Hybond nylon membrane (Amersham). One half was analyzed on UV-crosslinked membrane for DNA:RNA hybrids with S9.6; the other half was denatured with $0.5 \mathrm{M} \mathrm{NaOH}, 1.5 \mathrm{M}$ $\mathrm{NaCl}$, and neutralized with $1 \mathrm{M} \mathrm{NaCl}, 0.5 \mathrm{M}$ Tris- $\mathrm{HCl}$ pH 7.5 before UV crosslinking, then probed with mouse single-strand DNA antibody (Millipore) to detect total DNA. Bands of inputs and eluates were quantified using ImageJ.

Inputs and eluates were analyzed for enrichment of specific genes by quantitative PCR with SYBR Green in ABI PRISM7900HT PCR equipment (Applied Biosystems); the percentage of relative DRIP signal was calculated as a ratio of IP/input normalized to standard curves. Oligonucleotides are listed below.

\section{RNA sequencing}

Triplicate RNA probes from WT, DIDO $\triangle \mathrm{E} 16$, and DIDO $\triangle \mathrm{CT}+\mathrm{HADIDO} 3 \mathrm{mESC}$ were sequenced at the Centro Nacional de Análisis Genómico (CNAG-CRG), Barcelona, Spain. Illumina FastQ files containing $>77$ million paired-end reads per sample were provided by the CNAG-CRG, who also carried out quality control of the FastQ files.

\section{Computational analysis}

Data were obtained, processed, and annotated using R (R Development Core Team, 2014) and Bioconductor programs [71]. A genomic annotation for the UCSC mouse genome build GRCm38/mm10 (file knownGene.txt.gz) was downloaded from the site (ftp://hgdownload.cse.ucsc.edu/goldenPath/mm10/database/). Data for 3'UTR regions were added with the UCSC genePredToGtf tool. To assess read coverage distribution across the genome, bigWig files (10-bp genomic bins) were generated with bamCoverage/deepTools v2.3.1 [72] and normalized for differences. The aligned sequence reads, coverage, and ChIP-seq peaks were visualized with IGVtools [73].

\section{ChIP-seq analysis}

The genomic coordinates for HADIDO3 (GEO: GSE85029), RNA Pol II S2P (GEO: GSE34520), R-loops (GEO: GSE70189) and H3K4me3 (GEO: GSE36114) binding were transformed to the UCSC mouse genome build (mm10) using the liftOver tool (http://genome.ucsc.edu/cgi-bin/hgLiftOver). BED peak files were imported to RStudio and annotated using the R/Bioconductor package ChIPseeker [32]. The promoter region was set to $-1 \mathrm{~kb}$ to $200 \mathrm{bp}$ of the TSS. We also used the Bioconductor packages org.Mm.eg.db and TxDb.Mmusculus.UCSC.mm10.knownGene for peak annotations. Significance of overlap between ChIP-seq data sets was calculated using the enrichPeakOverlap function implemented in ChIPseeker, setting the number of random permutations (nShuffle) of the genomic locations to 10,000 .

\section{RNA-seq analysis}

Sequencing adapters and low-quality reads were removed. The sequences obtained were aligned with TopHat2 software [74]. For read counts and FPKM gene expression estimation, we used Cufflinks version 2.2.1 [75] We also used DEXSeq [31] to detect differential exon expression. Genes were filtered for significant differential expression using an adjusted $P$ value cutoff at 0.01 (after Benjamini-Hochberg multiple testing correction) and an absolute value of log2 fold change $\geq 0.7$ between DIDO3 $\triangle$ E16 mutant and WT ESC.

To study alterations in $3^{\prime}$ RNA isoform abundance, we reanalyzed the RNA-seq data. The Burrows-Wheeler aligner BWA-MEM 0.7.15 (http://biobwa.sourceforge.net) was used to align paired-end reads to the UCSC mouse genome build (mm10, http://genome.ucsc.edu/) with standard settings. Alignments were converted to BAM format and de-duplicated with Picard tools 2.9 .0 (http://broadinstitute.github.io/picard/). To quantify relative expression at $3^{\prime} \mathrm{UTR}+2 \mathrm{~kb}$ of transcripts, we ran StringTie 1.3.3 [76] using a modified GTF file with mm10-3'UTR annotations, and calculated the transcripts per million (TPM) reads. Sample scaling and statistical analyses were performed with the R package edgeR [73]. Transcripts with TPM $>0$ in all samples were kept for downstream analysis. Differentially expressed genes with an absolute value of log2 fold change $\geq 0.7$ and a false-discovery rate $(F D R)<0.05$ were considered statistically significant RNA-seq data have been deposited in the NCBI Gene Expression Omnibus (GEO) under accession number GSE152346.

\section{Quantification and statistical analysis}

The morphology and genotypes of mouse embryos were determined by investigators blinded to experimental groups. For biochemical analyses, a sufficient number of samples per genotype was used to determine biologically meaningful differences between experimental groups based on the variation in parameters as determined in previous studies. For assessment of image data, fields of view were selected to encompass a sufficiently large number of cells to ensure the capture of biologically meaningful differences, guided by previous data. Most results shown are representative of experiments repeated at least three times. Statistical data in graphs are reported as mean \pm Standard Error of the Mean (SEM) unless otherwise stated. Experimental group means were compared by unpaired two-tailed Student's $t$ test or ANOVA, depending on the number of groups. Normality of variables was assumed in most analysis, based on published results; variances were similar between experimental groups within each experiment. $P$ values $<0.05$ were considered significant.

\section{List of antibodies used}

\begin{tabular}{|c|c|c|c|c|}
\hline Specificity & Antibody & Dilution & $\begin{array}{l}\text { Source, } \\
\text { reference }\end{array}$ & Technique \\
\hline DIDO3 & $\begin{array}{l}\text { Rabbit } \\
\text { polyclonal }\end{array}$ & 1:400 & $\begin{array}{l}\text { Our laboratory, } \\
\text { PAB-Dido3 }\end{array}$ & IF \\
\hline NT-DIDO & $\begin{array}{l}\text { Mouse } \\
\text { monoclonal }\end{array}$ & 1:100 & $\begin{array}{l}\text { Our laboratory, } \\
\text { Dido MAB-1C6 }\end{array}$ & IF, WB \\
\hline OCT4 & $\begin{array}{l}\text { Mouse } \\
\text { monoclonal }\end{array}$ & $\begin{array}{l}1: 50 / \\
1: 1000\end{array}$ & $\begin{array}{l}\text { Santa Cruz; } \\
\text { sc-5279 }\end{array}$ & IF/WB \\
\hline SOX2 & $\begin{array}{l}\text { Rabbit } \\
\text { polyclonal }\end{array}$ & $1: 100$ & $\begin{array}{l}\text { Thermo Scientific; } \\
\text { PA1-16968 }\end{array}$ & IF \\
\hline NANOG & $\begin{array}{l}\text { Goat } \\
\text { polyclonal }\end{array}$ & $1: 25$ & $\begin{array}{l}\text { R\&D Systems; } \\
\text { AF2729 }\end{array}$ & IF \\
\hline SSEA1 & $\begin{array}{l}\text { Mouse } \\
\text { monoclonal }\end{array}$ & $1: 3$ & $\begin{array}{l}\text { University of } \\
\text { lowa; MC-480 }\end{array}$ & IF \\
\hline IUI & $\begin{array}{l}\text { Mouse } \\
\text { monoclonal }\end{array}$ & $1: 500$ & $\begin{array}{l}\text { Covance; } \\
\text { MMS-435P }\end{array}$ & IF \\
\hline FOXA2 & $\begin{array}{l}\text { Goat } \\
\text { polyclonal }\end{array}$ & $1: 50$ & $\begin{array}{l}\text { R\&D Systems; } \\
\text { AF2400 }\end{array}$ & IF \\
\hline ASMA & $\begin{array}{l}\text { Mouse } \\
\text { monoclonal }\end{array}$ & $1: 400$ & Sigma; A5228 & IF \\
\hline AFP & $\begin{array}{l}\text { Rabbit } \\
\text { polyclonal }\end{array}$ & $1: 400$ & Dako; A0008 & IF \\
\hline KLF3 & $\begin{array}{l}\text { Rabbit } \\
\text { polyclonal }\end{array}$ & $1: 800$ & $\begin{array}{l}\text { Sigma-Aldrich; } \\
\text { AV32186 }\end{array}$ & WB \\
\hline JAM2 & $\begin{array}{l}\text { Rat mono- } \\
\text { clonal }\end{array}$ & 1:100 & $\begin{array}{l}\text { R\&D Systems; } \\
\text { MAB988 }\end{array}$ & IF \\
\hline
\end{tabular}


Table continued

\begin{tabular}{|c|c|c|c|c|}
\hline Specificity & Antibody & Dilution & $\begin{array}{l}\text { Source, } \\
\text { reference }\end{array}$ & Technique \\
\hline $\begin{array}{l}\text { CARM1/ } \\
\text { PRMT4 }\end{array}$ & $\begin{array}{l}\text { Rabbit } \\
\text { polyclonal }\end{array}$ & $1: 1000$ & $\begin{array}{l}\text { Cell Signaling; } \\
4438\end{array}$ & WB \\
\hline HA-tag & $\begin{array}{l}\text { Mouse } \\
\text { monoclonal }\end{array}$ & $\begin{array}{l}1: 500 / \\
1: 1000\end{array}$ & $\begin{array}{l}\text { Covance; } \\
\text { MMS-101P }\end{array}$ & IF/WB \\
\hline WDR33 & $\begin{array}{l}\text { Mouse } \\
\text { monoclonal }\end{array}$ & $1: 100$ & $\begin{array}{l}\text { Santa Cruz; } \\
\text { sc-374466 }\end{array}$ & WB \\
\hline$\beta$-Actin & $\begin{array}{l}\text { Mouse } \\
\text { monoclonal }\end{array}$ & $1: 3000$ & $\begin{array}{l}\text { Sigma-Aldrich; } \\
\text { A3853 }\end{array}$ & WB \\
\hline $\begin{array}{l}\text { anti-DNA/ } \\
\text { RNA } \\
\text { hybrid, } \\
\text { clone S9.6 }\end{array}$ & $\begin{array}{l}\text { Mouse } \\
\text { monoclonal }\end{array}$ & $\begin{array}{l}1: 500 / \\
1: 1000 / \\
10 \mu g\end{array}$ & $\begin{array}{l}\text { Merck Millipore; } \\
\text { MABE } 1095 \text { and } \\
\text { purified AB, a } \\
\text { generous gift } \\
\text { from A. Aguilera }\end{array}$ & $\begin{array}{l}\text { IF/Slot } \\
\text { blot/IP }\end{array}$ \\
\hline$\gamma \mathrm{H} 2 \mathrm{Ax}$ & $\begin{array}{l}\text { Rabbit } \\
\text { polyclonal }\end{array}$ & $1: 600$ & $\begin{array}{l}\text { Bethyl; IHC-00059 } \\
\text { Novus Biologicals; } \\
\text { NB100-384 }\end{array}$ & IF \\
\hline $\mathrm{DHX9}$ & $\begin{array}{l}\text { Rabbit } \\
\text { polyclonal }\end{array}$ & $1: 1000$ & Abcam; ab26271 & $\mathrm{IP}, \mathrm{WB}$ \\
\hline $53 \mathrm{BP} 1$ & $\begin{array}{l}\text { Rabbit } \\
\text { polyclonal }\end{array}$ & $1: 500$ & Abcam; ab36823 & $\mathrm{IF}, \mathrm{WB}$ \\
\hline $\begin{array}{l}\text { Anti- } \\
\text { ssDNA }\end{array}$ & $\begin{array}{l}\text { Mouse } \\
\text { monoclonal }\end{array}$ & 1: 4000 & $\begin{array}{l}\text { Millipore; } \\
\text { MAB3868 }\end{array}$ & Slot blot \\
\hline $\begin{array}{l}\text { pCHK1 } \\
\text { (Ser345) }\end{array}$ & $\begin{array}{l}\text { Rabbit } \\
\text { polyclonal }\end{array}$ & $1: 1000$ & $\begin{array}{l}\text { Cell Signaling; } \\
2341\end{array}$ & WB \\
\hline
\end{tabular}

IF immunofluorescence, WB Western blot, IP immunoprecipitation

\section{Oligonucleotides}

\begin{tabular}{|c|c|c|c|}
\hline gene & Forward & Reverse & Method \\
\hline DIDO WT & GTGTGCTGGCACATTCAGGG & GTATTATATTTGGACGTGGTGATT & Genotyping \\
\hline $\begin{array}{l}\text { DIDO3-LoxP- } \\
\text { exon16 }\end{array}$ & GTGTGCTGGCACATTCAGGG & GTATTATATTTGGACGTGGTGATT & Genotyping \\
\hline $\mathrm{DIDO} 3 \Delta \mathrm{E} 16$ & GTGTGCTGGCACATTCAGGG & TCACATTGCCAAAAGACGGC & Genotyping \\
\hline $\begin{array}{l}\text { KLF3 short } \\
\text { isoform }\end{array}$ & GTATACCAGCCACCTGCAGC & AAACACCAGGTCTGCCTAAG & RT-PCR \\
\hline $\begin{array}{l}\text { KILF3 long } \\
\text { isoform }\end{array}$ & ACACTAAGAGCTCGCACTTG & CATGGAGAAACCGACAAATTG & RT-PCR \\
\hline $\begin{array}{l}\text { WDR33 short } \\
\text { 3'UTR }\end{array}$ & GTGTCCTGAGAAATGGAGCACC & TCCTACCTITCCTACCTITGC & RT-PCR \\
\hline $\begin{array}{l}\text { WDR33 long } 3^{\prime} \\
\text { UTR }\end{array}$ & AGACGAAAGACTGATGCCGAC & TCCTACCTITCCTACCTITGC & RT-PCR \\
\hline $\begin{array}{l}\text { JAM2 short } \\
\text { isoform }\end{array}$ & CCTTGGTCTACTACCAACAGG & GTAATACCATCCAGGCTGCTG & RT-PCR \\
\hline $\begin{array}{l}\text { JAM2 long } \\
\text { isoform }\end{array}$ & CTAAAGTCACTACGATGAGCG & GTCAGACACAAGATGCCAGG & RT-PCR \\
\hline $\begin{array}{l}\text { POU5f1 short } \\
\text { 3'UTR }\end{array}$ & CACATCGCCAATCAGCTTGG & TTGCCTTGGCTCACAGCATC & RT-PCR \\
\hline $\begin{array}{l}\text { POU5f1 long } \\
\text { 3'UTR }\end{array}$ & CACATCGCCAATCAGCTTGG & TCAGCAGTTAGGAGCTATGGC & RT-PCR \\
\hline HA-primer & GTACCCTTATGACGTGCCCG & & RT-PCR \\
\hline POU5f1 & CTGCCCAACTCCATGCTTGG & ATGGCATCGGCTAAAGCACC & ChIP, DRIP \\
\hline CARM1 & GAGGAGGGTACATCCTCAAC & CGGCACTATTGTCTACTGTGG & DRIP \\
\hline SOD3 & GCTTCGACCTAGCAGACAGG & CACCACGAAGTTGCCAAAGT & DRIP \\
\hline
\end{tabular}

\section{REFERENCES}

1. Takahashi K, Yamanaka S. A developmental framework for induced pluripotency. Development. 2015;142:3274-85.

2. Takahashi K, Yamanaka S. Induction of pluripotent stem cells from mouse embryonic and adult fibroblast cultures by defined factors. Cell. 2006;126: 663-76.

3. Yamanaka S. Pluripotency and nuclear reprogramming. Philos Trans R Soc Lond B Biol Sci. 2008;363:2079-87.
4. Niwa $\mathrm{H}$. The pluripotency transcription factor network at work in reprogramming. Curr Opin Genet Dev. 2014;28:25-31.

5. Kim HY, Jackson TR, Davidson LA. On the role of mechanics in driving mesenchymal-to-epithelial transitions. Semin Cell Dev Biol. 2017;67:113-22.

6. Cieply B, Park JW, Nakauka-Ddamba A, Bebee TW, Guo Y, Shang X, et al. Multiphasic and dynamic changes in alternative splicing during induction of pluripotency are coordinated by numerous RNA-binding proteins. Cell Rep. 2016;15:247-55.

7. Pradella D, Naro C, Sette C, Ghigna C. EMT and stemness: flexible processes tuned by alternative splicing in development and cancer progression. Mol Cancer. 2017;16:8.

8. Mueller AA, Cheung TH, Rando TA. All's well that ends well: alternative polyadenylation and its implications for stem cell biology. Curr Opin Cell Biol. 2013;25:222-32.

9. Gerstberger $S$, Hafner M, Tuschl T. A census of human RNA-binding proteins. Nat Rev Genet. 2014;15:829-45.

10. Mallanna SK, Rizzino A. Emerging roles of microRNAs in the control of embryonic stem cells and the generation of induced pluripotent stem cells. Dev Biol. 2010;344:16-25.

11. Skourti-Stathaki K, Proudfoot NJ. A double-edged sword: R loops as threats to genome integrity and powerful regulators of gene expression. Genes Dev. 2014:28:1384-96.

12. Santos-Pereira JM, Aguilera A. R loops: new modulators of genome dynamics and function. Nat Rev Genet. 2015;16:583-97.

13. Aguilera A, Garcia-Muse T. R loops: from transcription byproducts to threats to genome stability. Mol Cell. 2012;46:115-24.

14. Costantino L, Koshland D. The Yin and Yang of R-loop biology. Curr Opin Cell Biol. 2015;34:39-45.

15. Crossley MP, Bocek M, Cimprich KA. R-loops as cellular regulators and genomic threats. Mol Cell. 2019;73:398-411.

16. Chen PB, Chen HV, Acharya D, Rando OJ, Fazzio TG. R loops regulate promoterproximal chromatin architecture and cellular differentiation. Nat Struct Mol Biol. 2015;22:999-1007.

17. Fazzio TG. Regulation of chromatin structure and cell fate by R-loops. Transcription. 2016;7:121-6.

18. Li, Y, Song, Y, Xu, W, Li, Q, Wang, X, Li, K, et al. R-loops coordinate with SOX2 in regulating reprogramming to pluripotency. Sci Adv. 2020;6. https://doi.org/ 10.1126/sciadv.aba0777.

19. Brambati A, Colosio A, Zardoni L, Galanti L, Liberi G. Replication and transcription on a collision course: eukaryotic regulation mechanisms and implications for DNA stability. Front Genet. 2015;6:166.

20. Garcia-Muse T, Aguilera A. Transcription-replication conflicts: how they occur and how they are resolved. Nat Rev Mol Cell Biol. 2016;17:553-63.

21. Allison DF, Wang GG. R-loops: formation, function, and relevance to cell stress. Cell Stress. 2019;3:38-46.

22. Chedin F. Nascent connections: R-loops and chromatin patterning. Trends Genet. 2016;32:828-38.

23. Gatchalian J, Fütterer A, Rothbart SB, Tong $Q$, Rincon-Arano H, Sánchez de Diego $A$, et al. Dido3 PHD modulates cell differentiation and division. Cell Rep. 2013:4:148-58.

24. Trachana V, van Wely KH, Guerrero AA, Fütterer A, Martinez AC. Dido disruption leads to centrosome amplification and mitotic checkpoint defects compromising chromosome stability. Proc Natl Acad Sci USA. 2007;104:2691-6.

25. Guerrero AA, Gamero MC, Trachana V, Fütterer A, Pacios-Bras C, Díaz-Concha NP, et al. Centromere-localized breaks indicate the generation of DNA damage by the mitotic spindle. Proc Natl Acad Sci USA. 2010;107:4159-64.

26. Fütterer A, Campanero MR, Leonardo E, Criado LM, Flores JM, Hernández JM, et al. Dido gene expression alterations are implicated in the induction of hematological myeloid neoplasms. J Clin Invest. 2005;115:2351-62.

27. Fütterer A, Raya A, Llorente $M$, Izpisúa-Belmonte JC, de la Pompa JL, Klatt $P$, et al. Ablation of Dido3 compromises lineage commitment of stem cells in vitro and during early embryonic development. Cell Death Differ. 2012;19:132-43.

28. Fütterer A, de Celis J, Navajas R, Almonacid L, Gutiérrez J, Talavera-Gutiérrez A, et al. DIDO as a switchboard that regulates self-renewal and differentiation in embryonic stem cells. Stem Cell Rep. 2017;8:1062-75.

29. Mora Gallardo C, Sanchez de Diego A, Gutierrez Hernandez J, Talavera-Gutierrez A, Fischer T, Martinez AC, et al. Dido3-dependent SFPQ recruitment maintains efficiency in mammalian alternative splicing. Nucleic Acids Res. 2019;47:5381-94.

30. Hayashi S, Lewis P, Pevny L, McMahon AP. Efficient gene modulation in mouse epiblast using a Sox2Cre transgenic mouse strain. Mech Dev. 2002;119:S97-S101. Suppl 1

31. Anders S, Reyes A, Huber W. Detecting differential usage of exons from RNA-seq data. Genome Res. 2012;22:2008-17.

32. Yu G, Wang LG, He QY. ChIPseeker: an R/Bioconductor package for ChIP peak annotation, comparison and visualization. Bioinformatics. 2015;31:2382-3. 
33. Dang DT, Pevsner J, Yang VW. The biology of the mammalian Kruppel-like family of transcription factors. Int J Biochem Cell Biol. 2000;32:1103-21.

34. Chan SL, Huppertz I, Yao C, Weng L, Moresco JJ, Yates JR, et al. CPSF30 and Wdr33 directly bind to AAUAAA in mammalian mRNA $3^{\prime}$ processing. Genes Dev. 2014;28:2370-80.

35. Shi Y, Manley JL. The end of the message: multiple protein-RNA interactions define the mRNA polyadenylation site. Genes Dev. 2015;29:889-97.

36. Sakaguchi $T$, Nishimoto $M$, Miyagi $S$, Iwama $A$, Morita $Y$, Iwamori $N$, et al. Putative "stemness" gene jam-B is not required for maintenance of stem cell state in embryonic, neural, or hematopoietic stem cells. Mol Cell Biol. 2006;26:6557-70.

37. Matter K, Aijaz S, Tsapara A, Balda MS. Mammalian tight junctions in the regulation of epithelial differentiation and proliferation. Curr Opin Cell Biol. 2005;17:453-8.

38. Bedzhov, I, Graham, SJ, Leung, CY \& Zernicka-Goetz, M. Developmental plasticity, cell fate specification and morphogenesis in the early mouse embryo. Philos Trans R Soc Lond B Biol Sci. 2014;369:20130538.

39. Nichols J, Zevnik B, Anastassiadis K, Niwa H, Klewe-Nebenius D, Chambers I, et al. Formation of pluripotent stem cells in the mammalian embryo depends on the POU transcription factor Oct4. Cell. 1998;95:379-91.

40. Pesce $M$, Scholer HR. Oct-4: gatekeeper in the beginnings of mammalian development. Stem Cells. 2001;19:271-8.

41. Boiani M, Scholer HR. Regulatory networks in embryo-derived pluripotent stem cells. Nat Rev Mol Cell Biol. 2005;6:872-84.

42. Brookes E, de Santiago I, Hebenstreit D, Morris KJ, Carroll T, Xie SQ, et al. Polycomb associates genome-wide with a specific RNA polymerase II variant, and regulates metabolic genes in ESCs. Cell Stem Cell. 2012;10:157-70.

43. Yang $P$, Oldfield $A$, Kim $T$, Yang A, Yang JYH, Ho JWK. Integrative analysis identifies co-dependent gene expression regulation of BRG1 and CHD7 at distal regulatory sites in embryonic stem cells. Bioinformatics. 2017;33: 1916-20.

44. Komarnitsky $\mathrm{P}$, Cho EJ, Buratowski S. Different phosphorylated forms of RNA polymerase II and associated mRNA processing factors during transcription. Genes Dev. 2000;14:2452-60.

45. Ahn SH, Kim M, Buratowski S. Phosphorylation of serine 2 within the RNA polymerase II C-terminal domain couples transcription and $3^{\prime}$ end processing. Mol Cell. 2004;13:67-76.

46. Richard P, Manley JL. Transcription termination by nuclear RNA polymerases. Genes Dev. 2009;23:1247-69.

47. Sanz LA, Hartono SR, Lim YW, Steyaert S, Rajpurkar A, Ginno PA, et al. Prevalent, Dynamic, and conserved r-loop structures associate with specific epigenomic signatures in mammals. Mol Cell. 2016;63:167-78.

48. Cristini A, Groh M, Kristiansen MS, Gromak N. RNA/DNA hybrid interactome identifies DXH9 as a molecular player in transcriptional termination and R-loopassociated DNA damage. Cell Rep. 2018;23:1891-905.

49. Mazouzi A, Velimezi G, Loizou JI. DNA replication stress: causes, resolution and disease. Exp Cell Res. 2014;329:85-93.

50. Zeman MK, Cimprich KA. Causes and consequences of replication stress. Nat Cell Biol. 2014;16:2-9.

51. Fernandez-Vidal, A, Vignard, J \& Mirey, G Around and beyond 53BP1 Nuclear Bodies. Int J Mol Sci. 2017;18:2611.

52. Abad M, Mosteiro L, Pantoja C, Cañamero M, Rayon T, Ors I, et al. Reprogramming in vivo produces teratomas and iPS cells with totipotency features. Nature 2013;502:340-5.

53. Cheng D, Cote J, Shaaban S, Bedford MT. The arginine methyltransferase CARM1 regulates the coupling of transcription and mRNA processing. Mol Cell. 2007:25:71-83.

54. Kellner S, Kikyo N. Transcriptional regulation of the Oct4 gene, a master gene for pluripotency. Histol. Histopathol. 2010;25:405-12.

55. Mayr C. Regulation by 3'-untranslated regions. Annu Rev Genet. 2017;51:171-94

56. Proudfoot NJ. Transcriptional termination in mammals: stopping the RNA polymerase II juggernaut. Science. 2016;352:aad9926.

57. Skourti-Stathaki K, Proudfoot NJ, Gromak N. Human senataxin resolves RNA/DNA hybrids formed at transcriptional pause sites to promote Xrn2-dependent termination. Mol Cell. 2011;42:794-805.

58. Mayer A, Landry HM, Churchman LS. Pause \& go: from the discovery of RNA polymerase pausing to its functional implications. Curr Opin Cell Biol. 2017;46:72-80

59. $\mathrm{YU}$ X, Martin PGP, Michaels SD. BORDER proteins protect expression of neighboring genes by promoting $3^{\prime}$ Pol II pausing in plants. Nat Commun. 2019;10:4359.

60. Sollier J, Cimprich KA. Breaking bad: R-loops and genome integrity. Trends Cell Biol. 2015;25:514-22.

61. Chakraborty P, Huang JTJ, Hiom K. DHX9 helicase promotes R-loop formation in cells with impaired RNA splicing. Nat Commun. 2018;9:4346.
62. Gulliver C, Hoffmann R, Baillie GS. The enigmatic helicase DHX9 and its association with the hallmarks of cancer. Future Sci OA. 2020;7:Fso650.

63. Chakraborty, P \& Hiom, K. DHX9-dependent recruitment of BRCA1 to RNA is required to promote DNA end resection in homologous recombination. Preprint bioRxiv at https://doi.org/10.1101/2019.12.20.884593 (2019).

64. González F, Georgieva D, Vanoli F, Shi Z-D, Stadtfeld M, Ludwig T, et al. Homologous recombination DNA repair genes play a critical role in reprogramming to a pluripotent state. Cell Rep. 2013;3:651-60.

65. Chen L, Chen J-Y, Zhang X, Gu Y, Xiao R, Shao C, et al. R-ChIP using inactive RNase $\mathrm{H}$ reveals dynamic coupling of R-loops with transcriptional pausing at gene promoters. Mol Cell. 2017;68:745-757.e745.

66. Vanoosthuyse V. Strengths and weaknesses of the current strategies to map and characterize R-loops. Non-Coding RNA. 2018;4:9.

67. Promonet, A, Padioleau, I, Liu, Y, Sanz, L, Biernacka, A, Schmitz, A-L, et al. Topoisomerase 1 prevents replication stress at R-loop-enriched transcription termination sites. Nat Commun. 2020;11:3940.

68. Chakraborty P. New insight into the biology of R-loops. Mutat Res. 2020;821:111711.

69. Ginno PA, Lott PL, Christensen HC, Korf I, Chedin F. R-loop formation is a distinctive characteristic of unmethylated human $\mathrm{CpG}$ island promoters. Mol Cell. 2012;45:814-25.

70. Sanz LA, Chedin F. High-resolution, strand-specific R-loop mapping via S9.6based DNA-RNA immunoprecipitation and high-throughput sequencing. Nat Protoc. 2019;14:1734-55.

71. Huber W, Carey VJ, Gentleman R, Anders S, Carlson M, Carvalho BS, et al. Orchestrating high-throughput genomic analysis with Bioconductor. Nat Methods. 2015;12:115-21.

72. Ramírez F, Ryan DP, Grüning B, Bhardwaj V, Kilpert F, Richter AS, et al. deepTools2: a next generation web server for deep-sequencing data analysis. Nucleic Acids Res. 2016;44:W160-165.

73. Robinson MD, McCarthy DJ, Smyth GK. edgeR: a Bioconductor package for differential expression analysis of digital gene expression data. Bioinformatics. 2010;26:139-40.

74. Kim D, Pertea G, Trapnell C, Pimentel H, Kelley R, Salzberg SL. TopHat2: accurate alignment of transcriptomes in the presence of insertions, deletions and gene fusions. Genome Biol. 2013;14:R36.

75. Trapnell C, Williams BA, Pertea G, Mortazavi A, Kwan G, van Baren MJ, et al. Transcript assembly and quantification by RNA-Seq reveals unannotated transcripts and isoform switching during cell differentiation. Nat Biotechnol. 2010;28:511-5

76. Pertea M, Pertea GM, Antonescu CM, Chang TC, Mendell JT, Salzberg SL. StringTie enables improved reconstruction of a transcriptome from RNA-seq reads. Nat Biotechnol. 2015;33:290-5.

\section{ACKNOWLEDGEMENTS}

The authors thank especially Manuel Serrano from the Spanish National Cancer Research Center (CNIO), Madrid and Institute for Research in Biomedicine (IRB), Barcelona for providing reprogrammable Tg(tetO-POU5f1,SOX2,KLF4,MYC)1Srn mice, and Miguel Torres from the Spanish National Cardiovascular Research Center (CNIC), Madrid for providing Tg(SOX2-Cre)1Amc mice for Cre-recombination. We also thank Luis Almonacid from the CNB Genomics Unit, Q-PCR facility, the CNB facility for flow cytometry, and Catherine Mark for editorial assistance.

\section{AUTHOR CONTRIBUTIONS}

AF designed, performed, and analyzed most experiments and wrote the paper with input from all authors. AT-G performed and analyzed experiments. TP and JdC analyzed the transcriptome and ChIP-seq data. JG performed some experiments and co-wrote the paper and VDP performed some experiments. CMA conceptualized experiments, supervised the work, co-wrote the paper, and secured funding.

\section{FUNDING}

This work was supported by grants SAF2016-75456-R and PID2019-110574RB-I00 from the Spanish Ministerio de Ciencia e Innovacion, from the Comunidad de Madrid (MITIC), from Intramural Project PIE 201920 E017 and from the BBVA Foundation.

\section{COMPETING INTERESTS}

The authors declare no competing interests. 
14

\section{ETHICS STATEMENT}

All animal experiments were designed in compliance with European Union legislation and approved by the Committee for Ethics in Animal Experimentation of the Centro Nacional de Biotecnología (CNB/CSIC) (Proex 322/15).

\section{ADDITIONAL INFORMATION}

Supplementary information The online version contains supplementary material available at https://doi.org/10.1038/s41419-021-03906-2.

Correspondence and requests for materials should be addressed to C.M-A.

Reprints and permission information is available at http://www.nature.com/reprints

Publisher's note Springer Nature remains neutral with regard to jurisdictional claims in published maps and institutional affiliations. (c) Open Access This article is licensed under a Creative Commons Attribution 4.0 International License, which permits use, sharing, adaptation, distribution and reproduction in any medium or format, as long as you give appropriate credit to the original author(s) and the source, provide a link to the Creative Commons license, and indicate if changes were made. The images or other third party material in this article are included in the article's Creative Commons license, unless indicated otherwise in a credit line to the material. If material is not included in the article's Creative Commons license and your intended use is not permitted by statutory regulation or exceeds the permitted use, you will need to obtain permission directly from the copyright holder. To view a copy of this license, visit http://creativecommons. org/licenses/by/4.0/.

(c) The Author(s) 2021 